\section{Selective loss of function variants in IL6ST cause Hyper-IgE syndrome with distinct impairments of T-cell phenotype and function}

Tala Shahin, ${ }^{1,2^{*}}$ Dominik Aschenbrenner, ${ }^{3^{*}}$ Deniz Cagdas, ${ }^{4,5^{*}}$

Sevgi Köstel Bal, ${ }^{1,2,6}$ Cecilia Domínguez Conde, ${ }^{1,2}$ Wojciech Garncarz,, David Medgyesi, ${ }^{1,2}$ Tobias Schwerd, ${ }^{3,7}$ Betül Karaatmaca, ${ }^{4}$

Pınar Gur Cetinkaya, ${ }^{4}$ Saliha Esenboga, ${ }^{4}$ Stephen R. F. Twigg, ${ }^{8}$ Andrew Cant, ${ }^{9}$ Andrew O. M. Wilkie, ${ }^{8}$ Ilhan Tezcan, ${ }^{4,5}$ Holm H. Uhlig ${ }^{3,10}$ and Kaan Boztug ${ }^{1,2,11,12}$

${ }^{1}$ Ludwig Boltzmann Institute for Rare and Undiagnosed Diseases, Vienna, Austria; ${ }^{2}$ CeMM Research Center for Molecular Medicine of the Austrian Academy of Sciences, Vienna, Austria; ${ }^{3}$ Translational Gastroenterology Unit, John Radcliffe Hospital, University of Oxford, UK; ${ }^{4}$ Section of Pediatric Immunology, Insan Doğramacı Children's Hospital, Hacettepe University, Ankara, Turkey; ${ }^{5}$ Institute of Child Health, Hacettepe University, Ankara, Turkey; ${ }^{6}$ Department of Pediatric Allergy and Immunology, Ankara University School of Medicine, Cebeci, Turkey; 'Dr. von Hauner Children's Hospital, LudwigMaximilians-University of Munich, Germany; ${ }^{8}$ Clinical Genetics Group, MRC Weatherall Institute of Molecular Medicine, John Radcliffe Hospital, University of Oxford, UK; Institute of Cellular Medicine, Newcastle University, Newcastle upon Tyne, UK;

${ }^{10}$ Department of Paediatrics, University of Oxford, UK; ${ }^{11}$ Department of Pediatrics and Adolescent Medicine, Medical University of Vienna, Austria and ${ }^{12}$ St. Anna Kinderspital and Children's Cancer Research Institute, Department of Pediatrics, Medical University of Vienna, Austria

${ }^{\star} T S h, D A$ and DC contributed equally to this work. ${ }^{*} \mathrm{HHU}$ and $\mathrm{KB}$ are co-senior authors.

\section{ABSTRACT}

$\mathrm{H}$ yper-IgE syndromes comprise a group of inborn errors of immunity. STAT3-deficient hyper-IgE syndrome is characterized by elevated serum IgE levels, recurrent infections and eczema, and characteristic skeletal anomalies. A loss-of-function biallelic mutation in IL6ST encoding the GP130 receptor subunit (p.N404Y) has very recently been identified in a singleton patient (herein referred to as $\mathrm{P}^{\mathrm{N} 404 \mathrm{Y}}$ ) as a novel etiology of hyper-IgE syndrome. Here, we studied a patient with hyper-IgE syndrome caused by a novel homozygous mutation in IL6ST (p.P498L; patient herein referred to as P(498L) leading to abrogated GP130 signaling after stimulation with IL-6 and IL-27 in peripheral blood mononuclear cells as well as IL- 6 and IL-11 in fibroblasts. Extending the initial identification of selective GP130 deficiency, we aimed to dissect the effects of aberrant cytokine signaling on T-helper cell differentiation in both patients. Our results reveal the importance of IL-6 signaling for the development of CCR6-expressing memory $\mathrm{CD}^{+} \mathrm{T}$ cells (including T-helper 17-enriched subsets) and non-conventional CD8 ${ }^{+} \mathrm{T}$ cells which were reduced in both patients. Downstream functional analysis of the GP130 mutants (p.N404Y and p.P498L) have shown differences in response to IL-27, with the p.P498L mutation having a more severe effect that is reflected by reduced T-helper 1 cells in this patient ( $\left.\mathrm{P}^{\mathrm{P} 498 \mathrm{~L}}\right)$ only. Collectively, our data suggest that characteristic features of GP130-deficient hyper-IgE syndrome phenotype are IL- 6 and IL-11 dominated, and indicate selective roles of aberrant IL- 6 and IL-27 signaling on the differentiation of $\mathrm{T}$-cell subsets.

\section{Introduction}

Hyper-IgE syndromes (HIES) comprise a group of primary immunodeficiencies (PIDs) associated with recurrent pulmonary infections, eczema and skin abscesses. As a subtype of HIES, autosomal-dominant STAT3 deficiency also involves skeletal abnormalities including scoliosis, craniosynostosis and retained dentition. ${ }^{1-4} \mathrm{We}$

Ferrata Storti Foundation

Haematologica 2019

Volume 104(3):609-621

\section{Correspondence:}

KAAN BOTZUG

kaan.boztug@rud.Ibg.ac.at

HOLM H. UHLIG

holm.uhlig@ndm.ox.ac.uk

Received: March 26, 2018.

Accepted: October 3, 2018.

Pre-published: October 11, 2018.

doi:10.3324/haematol.2018.194233

Check the online version for the most updated information on this article, online supplements, and information on authorship \& disclosures: www.haematologica.org/content/104/3/609

(C)2019 Ferrata Storti Foundation

Material published in Haematologica is covered by copyright. All rights are reserved to the Ferrata Storti Foundation. Use of published material is allowed under the following terms and conditions:

https://creativecommons.org/licenses/by-nc/4.0/legalcode. Copies of published material are allowed for personal or internal use. Sharing published material for non-commercial purposes is subject to the following conditions: https://creativecommons.org/licenses/by-nc/4.0/legalcode, sect. 3. Reproducing and sharing published material for commercial purposes is not allowed without permission in writing from the publisher. 
recently identified a singleton patient (herein referred to as $\mathrm{P}^{\mathrm{N} 404 \mathrm{Y}}$ ) carrying a homozygous loss-of-function mutation in IL6ST (p.N404Y) encoding the cytokine receptor subunit GP130 with remarkable clinical manifestations resembling that of STAT3 HIES, whereby $\mathrm{P}^{\mathrm{N} 404 \mathrm{Y}}$ experienced recurrent infections, eczema, elevated IgE, eosinophilia, impaired acute-phase response, scoliosis and craniosynostosis. ${ }^{5}$

The GP130 subunit binds to several cytokine receptors including IL-6 receptor alpha (IL-6RA), IL-11RA, IL-27RA, leukemia inhibitory factor (LIF) receptor, oncostatin $M$ (OSM) receptor and ciliary neurotrophic factor (CNTF) receptor. Upon stimulation with the respective cytokine, several JAK/STAT pathways are activated downstream of these receptors. ${ }^{6}$ The importance of GP130-mediated signaling was shown in $116 \mathrm{st}^{1 /}$ mice that die embryonically due to myocardial and hematopoietic defects. ${ }^{7}$ Moreover, postnatal conditional inactivation of gp130 in mice leads to neurological, hepatic and immunological defects with impaired acute-phase response, increased susceptibility to infections, and development of lung emphysema. ${ }^{8}$ With regards to cytokines, the contribution of IL-6 signaling to immune responses against pathogens has been emphasized in Il-6-deficient mice as well as in children with autoantibodies against IL-6. ${ }^{9-12}$ The roles of other GP130dependent cytokines in the context of disease have been studied, whereby the importance of IL-27 signaling has been shown in mediating T-cell responses, IL-11 in bone development, LIF in hematopoiesis and thymocyte development, and CTNF in the maintenance of motor neurons. $^{13-17}$

Here, we identify a patient harboring a novel biallelic mutation in IL6ST (herein referred to as $\mathrm{P}^{\mathrm{P} 498 \mathrm{~L}}$ ), presenting with elevated IgE levels, recurrent infections, severe atopic dermatitis, and characteristic skeletal abnormalities. We observe complete or partial disruption of selected cytokine signaling pathways in various cell types from $\mathrm{P}^{\mathrm{P} 498 \mathrm{~L}}$. We extend our initial findings on human GP130 deficiency by comparatively dissecting signaling defects and perturbations in T-cell differentiation in the $\mathrm{P}^{\mathrm{P} 498 \mathrm{~L}}$ patient and our previously reported patient $\left(\mathrm{P}^{\mathrm{N} 404 \mathrm{Y}}\right) .{ }^{5}$ Finally, we pinpoint selective roles of impaired IL-6, IL-11 and IL-27 signaling in the presence of other functional cytokine signaling pathways such as IL-21 and IL-10.

\section{Methods}

\section{Subjects}

Patients and healthy controls were included with informed written consent and approval from the Institutional Review Boards of the Medical University of Vienna, Hacettepe University Medical School in Ankara, Oxfordshire Research Ethics Committee B, the London Riverside Research Ethics Committee, and Oxford Gastrointestinal Illness Biobank. ${ }^{5}$

\section{GP130 expression analysis}

Patient and healthy donor fibroblasts were detached by incubation with $50 \mathrm{mM}$ EDTA in PBS for 30 minutes (min) on ice followed by gentle scraping with a silicon blade (CytoOne ${ }^{\circledR}$ ). Cells were immediately washed with PBS and stained with GP130BV421 or an isotype control, CD4-BV421 (both IgG1к), for $35 \mathrm{~min}$ on ice. Cells were washed and resuspended in PBS for flow cytometry analysis.

\section{p-STAT analysis by flow cytometry}

Peripheral blood mononuclear cells (PBMCs). Frozen PBMCs from patient and healthy donor controls were thawed and allowed to recover for four hours (h) at $37^{\circ} \mathrm{C}$ in complete media (RPMI-1640 with $10 \%$ FBS). Cells were subsequently stained with CD3-FITC, CD4-BV605, CD8-V450 and CD19-PECy7 for $20 \mathrm{~min}$ at $37^{\circ} \mathrm{C}$. Five minutes through the extracellular staining, cells were stimulated for $15 \mathrm{~min}$ at $37^{\circ} \mathrm{C}$ with IL-6, IL-21, IL-27 (all $100 \mathrm{ng} / \mathrm{mL}$ ) or IL-10 $(50 \mathrm{ng} / \mathrm{mL})$. Cells were then immediately fixed for $10 \mathrm{~min}$ at $37^{\circ} \mathrm{C}$, washed and permeabilized for $35 \mathrm{~min}$ on ice. Cells were then stained with p-STAT3-AF647 for $1 \mathrm{~h}$ at room temperature, washed again, and resuspended in FACS buffer for flow cytometry analysis.

Tlymphoblasts and Epstein-Barr virus-transformed lymphoblastoid cell lines ( $E B V$-LCLs). T lymphoblasts from patient and healthy donors were starved for $2 \mathrm{~h}$ in T-cell media (RPMI-1640 with 5\% humanserum) without IL-2, while EBV-LCLs were starved for 2-3 $\mathrm{h}$ in serum-deprived media (RPMI-1640). Cells were then stimulated with the cytokines mentioned and p-STAT staining performed as described above. (See Online Supplementary Table S1 for all antibodies used.)

Fibroblasts and HEK293 GP130-KO cell line. Fibroblasts and HEK293 GP130-KO cells ${ }^{5}$ were grown in complete media (DMEM with $10 \% \mathrm{FBS}$ ) in 12-well and 96-well plates, respectively. Fibroblasts and HEK293 GP130-KO cells were serum-starved overnight or for $2-3 \mathrm{~h}$, respectively, followed by stimulation with increasing concentrations $(0.01,0.1,1,10,100 \mathrm{ng} / \mathrm{mL})$ of IL- 6 , IL11, IL-27, LIF and OSM cytokines for $15 \mathrm{~min}$, immediate detachment using Trypsin-EDTA, and fixation for $10 \mathrm{~min}$ at $37^{\circ} \mathrm{C}$. The p-STAT staining was performed as described above.

HEK293 GP130-KO cells were transiently transfected with empty plasmid [pcDNA3.1(+)] or plasmid encoding WT or mutant GP130 using Lipofectamine 2000 (Thermo Fisher) before p-STAT3 analysis as previously described. ${ }^{5}$ Cells were co-transfected with either IL-6RA or IL-11RA to enhance the phosphorylation signal. GFP-coding plasmid was co-transfected to allow gating on successfully transfected cells.

\section{Intracellular cytokine staining}

T-cell cytokine production was analyzed in $0.5-1 \times 10^{6}$ total PBMCs that were stimulated for $5 \mathrm{~h}$ with Phorbol 12 -myristate 13-acetate (PMA, $0.2 \mu \mathrm{M})$ and Ionomycin $(1 \mu \mathrm{g} / \mathrm{mL})$ with the addition of Brefeldin A during the final $2.5 \mathrm{~h}$. To identify T-cell subpopulations, surface staining was performed as indicated below. Subsequently, cells were fixed, permeabilized and stained for intracellular cytokines followed by flow cytometry analysis. The following antibodies were used: IL-4, IL-10, IL-13, IL-17A, IL-22, IFN- $\gamma$ and TNF. Dead cells were excluded from analysis by staining with fixable viability dye eFluor780 (eBioscience).

\section{Chemokine receptor profiling}

For the analysis of surface marker expression by flow cytometry, $0.5-1 \times 10^{6}$ total PBMCs were incubated with fluorochromeconjugated antibodies for $15 \mathrm{~min}$ in $\mathrm{PBS}$ supplemented with $0.5 \%$ human serum at $37^{\circ} \mathrm{C}$ or room temperature, as assessed by titration experiments at both temperatures. To exclude dead cells from the analysis, cells were stained with fixable viability dye eFluor780 (eBioscience). Antibodies used for cell surface immunophenotyping included: CD3, TCR $\alpha \beta, \mathrm{CD} 4, \mathrm{CD} 8, \mathrm{CD} 25, \mathrm{CD} 45 \mathrm{RA}, \mathrm{CD} 127$, CCR4, CCR6, CCR7, CCR9, CCR10, CXCR3, CXCR5, CRTh2. All samples were acquired using the Beckman Coulter CytoFlex, BD LSRII or BD LSR Fortessa. Other methods and details of the antibodies used can be found in Online Supplementary Table S1. 
Table 1. Immunological characterization, immunoglobulin and eosinophil values of $\mathrm{P}^{\mathrm{P} 498 \mathrm{~L}}$.

\begin{tabular}{|c|c|c|c|c|c|}
\hline Age at evaluation & & $1.8 \mathrm{mo}$ & $9.9 \mathrm{yr}$ & & $12.7 \mathrm{yr}$ \\
\hline \multicolumn{6}{|l|}{ Lymphocyte subsets } \\
\hline \multirow[t]{2}{*}{ Absolute lymphocyte count, $\mathrm{g} / \mathrm{L}$} & & 8000 & 3600 & & 3500 \\
\hline & & $(3500-13100)$ & $(1100-5900)$ & & $(1000-5300)$ \\
\hline \multirow[t]{2}{*}{$\mathrm{CD}^{+} \mathrm{T}$ cells, cells $/ \mu \mathrm{L}$} & & 6480 & 2772 & & 2555 \\
\hline & & $(2300-7000)$ & $(700-4200)$ & & $(800-3500)$ \\
\hline \multirow[t]{2}{*}{ CD4 ${ }^{+} \mathrm{T}$ cells, cells/ $\mu \mathrm{L}$} & & 4640 & 1584 & & 1610 \\
\hline & & $(1700-5300)$ & $(300-2000)$ & & $(400-2100)$ \\
\hline \multirow[t]{2}{*}{$\mathrm{CD} 45 \mathrm{RA}^{+} \mathrm{CCR} 7^{+}, \%$} & & ND & ND & & 61.2 \\
\hline & & & & & $(57.4-84.9)$ \\
\hline \multirow[t]{2}{*}{$\mathrm{CD}^{2} 5 \mathrm{RA}-\mathrm{CCR} 7^{+}, \%$} & & ND & ND & & 6.9 \\
\hline & & & & & $(11.3-26.7)$ \\
\hline \multirow[t]{2}{*}{ CD45RA-CCR7-, \% } & & ND & ND & & 18.2 \\
\hline & & & & & $(3.3-15.2)$ \\
\hline \multirow[t]{2}{*}{ CD45RA+CCR7-, \% } & & ND & ND & & 13.7 \\
\hline & & & & & $(0.4-2.6)$ \\
\hline \multirow[t]{2}{*}{ CD8 ${ }^{+} \mathrm{T}$ cells, cells $/ \mu \mathrm{L}$} & & 2080 & 1008 & & 945 \\
\hline & & $(400-1700)$ & $(300-1800)$ & & $(200-1200)$ \\
\hline \multirow[t]{2}{*}{$\mathrm{CD} 45 \mathrm{RA}^{+} \mathrm{CCR} 7^{+}, \%$} & & ND & ND & & 29.7 \\
\hline & & & & & $(28.4-80.6)$ \\
\hline \multirow[t]{2}{*}{$\mathrm{CD}^{2} 5 \mathrm{RA}^{-\mathrm{CCR}} 7^{+}, \%$} & & ND & ND & & 5.5 \\
\hline & & & & & $(1.4-5)$ \\
\hline \multirow[t]{2}{*}{$\mathrm{CD}^{2} 5 \mathrm{RA}^{-} \mathrm{CCR}^{-}, \%$} & & ND & ND & & 12.3 \\
\hline & & & & & $(6.2-29.3)$ \\
\hline \multirow[t]{2}{*}{ CD45RA+CCR7-, \% } & & ND & ND & & 29.7 \\
\hline & & & & & $(9.1-49.1)$ \\
\hline \multirow[t]{2}{*}{$\mathrm{CD} 4 / \mathrm{CD} 8$} & & 2.23 & 1.57 & & 1.7 \\
\hline & & $(1.3-6.3)$ & $(0.9-2.6)$ & & $(0.9-3.4)$ \\
\hline \multirow[t]{2}{*}{ CD56+CD16+ NK cells, cells/uL } & & 480 & 324 & & ND \\
\hline & & $(200-1400)$ & $(90-900)$ & & \\
\hline \multirow[t]{2}{*}{ CD19+ $\mathrm{B}$ cells, cells/ $\mu \mathrm{L}$} & & 880 & 216 & & 56.7 \\
\hline & & $(549-1225)$ & $(228-516)$ & & $(226-370)$ \\
\hline \multirow[t]{2}{*}{ CD27-IgD', $\%$} & & ND & ND & & 90.5 \\
\hline & & & & & $(75.2-86.7)$ \\
\hline \multirow[t]{2}{*}{$\mathrm{CD}^{2} 7^{+} \operatorname{IgD} \mathrm{D}^{+}, \%$} & & ND & ND & & 6 \\
\hline & & & & & $(4.6-10.2)$ \\
\hline \multirow[t]{2}{*}{$\mathrm{CD} 27+\operatorname{IgD}, \%$} & & ND & ND & & 5.1 \\
\hline & & & & & $(3.3-9.6)$ \\
\hline Age at evaluation & $1.8 \mathrm{mo}$ & $6.5 \mathrm{yr}$ & $9.9 \mathrm{yr}$ & $12.1 \mathrm{yr}$ & $12.7 \mathrm{yr}$ \\
\hline \multicolumn{6}{|l|}{ Immunoglobulin } \\
\hline \multirow[t]{2}{*}{$\operatorname{IgG}(g / L)$} & 5.19 & 19.80 & 13.10 & 12.60 & 15.80 \\
\hline & $(7.5-15.5)$ & $(6.5-14.1)$ & $(7.3-13.5)$ & $(7.7-15.1)$ & $(7.7-15.1)$ \\
\hline $\operatorname{IgM}(g / L)$ & 0.24 & 1.07 & 1.23 & 1.61 & 1.86 \\
\hline & $(0.12-0.87)$ & $(0.55-2.1)$ & $(0.8-1.5)$ & $(0.7-1.5)$ & $(0.7-1.5)$ \\
\hline $\operatorname{IgA}(g / L)$ & 0.073 & 1.28 & 0.94 & 1.12 & 1.46 \\
\hline & $(0.06-0.58)$ & $(0.83-2.17)$ & $(0.70-2.22)$ & $(1.08-3.25)$ & $(1.08-3.25)$ \\
\hline $\operatorname{IgE}(\mathrm{IU} / \mathrm{L})$ & 6.71 & 2433 & 2788 & 2788 & 6974 \\
\hline & $(2-34)$ & $(2-307)$ & $(2-696)$ & $(2-696)$ & $(2-696)$ \\
\hline Eosinophils (g/L) & 6.3 & $\mathrm{NA}$ & 0.6 & 1.1 & 2.5 \\
\hline & $(0.02-0.85)$ & $(-)$ & $(0.0-0.5)$ & $(0.0-0.5)$ & $(0.0-0.5)$ \\
\hline
\end{tabular}

Reference ranges for B-cell absolute counts and percentages of naïve/memory subsets were obtained from a previously published cohort. ${ }^{46}$ Values out of range are shown in bold. mo: months; yr: years; ND: not determined; NA: not available. 
A
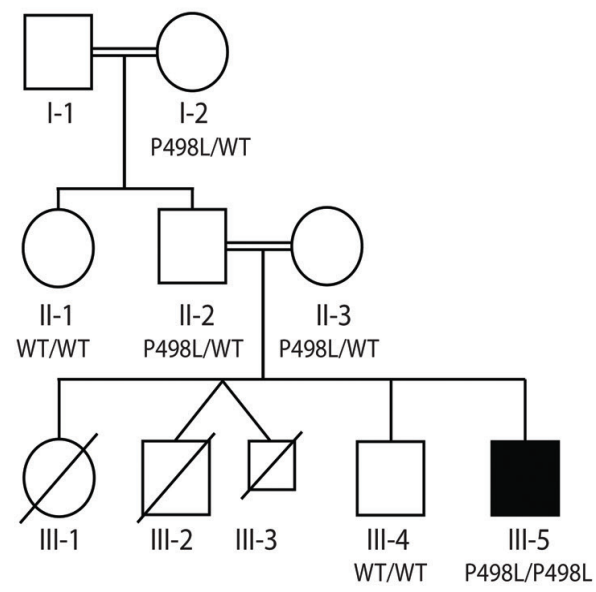
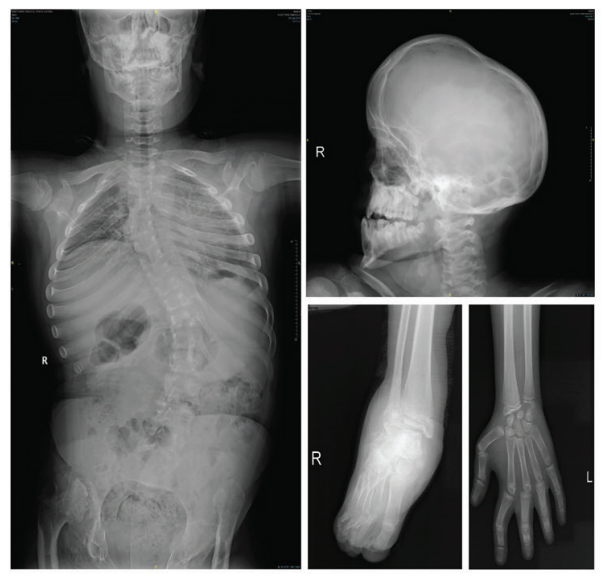

C
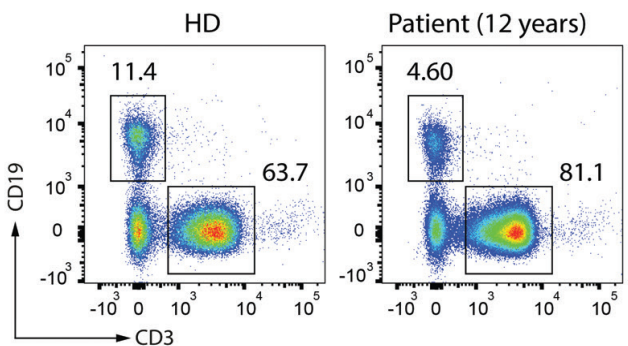

E
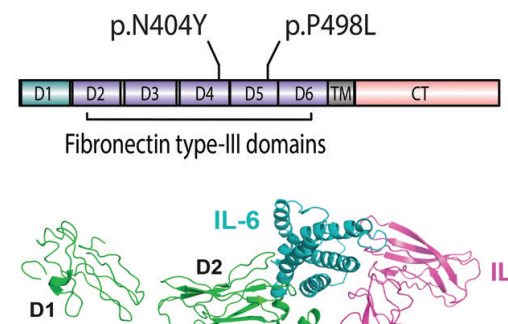

IL-6 8 aces

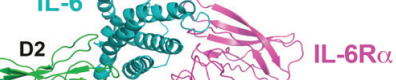

GP130 (D1-DG

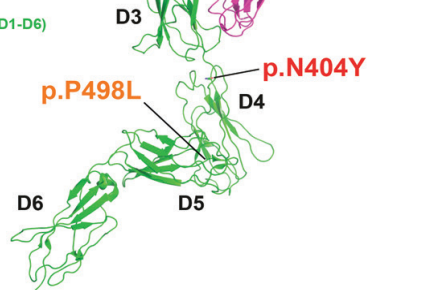

D

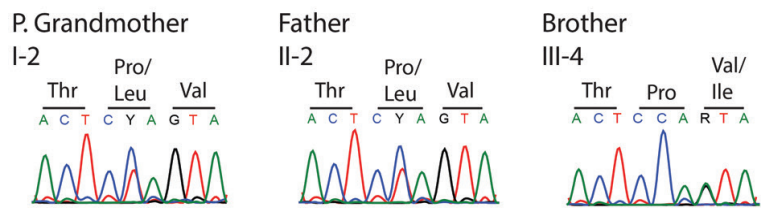

P. Aunt

II-1

Mother

II-3

Patient

III-5

$\frac{\text { Thr }}{A C T} \frac{\text { Pro }}{C C M} \frac{\text { Val }}{G T A}$

soldand $\frac{\text { Thr }}{A C T} \frac{\text { Leu }}{C T A} \frac{\text { Val }}{G T A}$

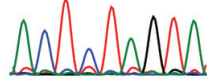

F

G

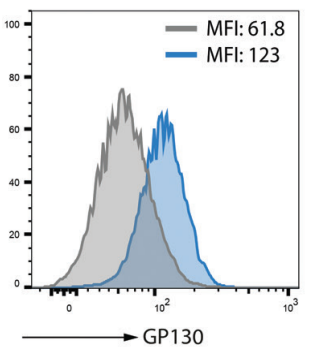

- Isotype

— HD Fibroblast

— p.P498L Fibroblast

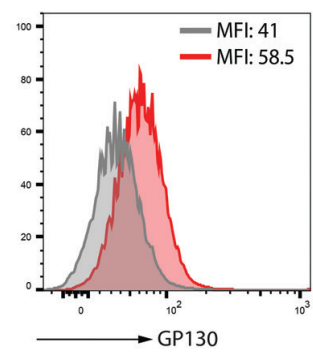

Figure 1. Identification of a novel IL6ST variant in $\mathrm{P}^{\mathrm{P} 498 \mathrm{~L}}$. (A) Pedigree of $\mathrm{P}^{\mathrm{P} 498 \mathrm{~L}}$ showing consanguinity in the family. $\mathrm{P}^{\mathrm{P} 498 \mathrm{~L}}$ has 3 deceased siblings, a sister, and twin brothers [one who died in utero (III-3)], and a brother who has congenital blindness of unknown etiology but is unremarkable for his immune system. $\mathrm{P}^{\mathrm{p} 498 \mathrm{~L}}$ is homozygous for IL6ST c.1493C>T (p.P498L/p.P498L). (B) X-ray images of P P498L showing scoliosis (left), scaphocephaly (top right), edema in the right ankle (bottom center), and flexion contractures of the small joints in the hand (bottom right). (C) Flow cytometry plot illustrating a reduction in CD19+ $B$ cells and normal CD3 ${ }^{+} \mathrm{T}$ cells in PBMCs of $\mathrm{P}^{\mathrm{P} 498 \mathrm{~L}}$ at the of age 12.4 years. (D) Sanger sequencing of the identified IL6ST variant (c.1493C $>T$ ) in $\mathrm{P}^{\mathrm{P} 498 \mathrm{~L}}$ and family members. (E) Linear representation of GP130 and crystal structure of the GP130-IL6-IL6R $\alpha$ complex (adapted and modified ${ }^{5}$ ) outlining the protein domains and the two mutations found in P P498L and the previously described patient ( $\mathrm{P}^{\mathrm{N} 404 \mathrm{Y}}$; p.N404Y). D: domains; TM: transmembrane domain; CT: cytoplasmic tail. ( $\mathrm{F}$ ) Conservation of the amino acid proline at position 498 across species including some adjacent amino acids. (G) Flow cytometry analysis of GP130 expression in fibroblasts of P(498L compared to that of a healthy donor. Average of mean fluorescence intensity (MFI) from 2-3 technical replicates is shown on the top right area of the graphs. 
IL6ST variants lead to aberrant T-cell phenotype

Results

Clinical disease manifestation and immunological characterization of Patient $\mathrm{P}^{\mathrm{p} 498 \mathrm{~L}}$

Patient $\mathrm{P}^{\mathrm{P} 49 \mathrm{~L} \mathrm{~L}}$ was born to consanguineous Turkish parcents (first-degree cousins) (Figure 1A). He experienced diarrhea at one month of age, recurrent otitis media, bilataral keratitis, and recurrent respiratory infections including pneumonia (Serratia marcescens and Pseudomonas aeruginosa were isolated) complicated by empyema and pneumothorax. In addition, he was followed up for severe eczema and food allergy (milk, egg and wheat; class III).

A Primary T-cells

IL -6

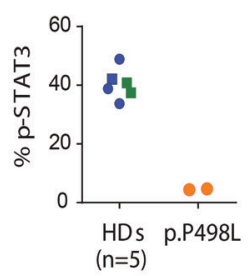

B
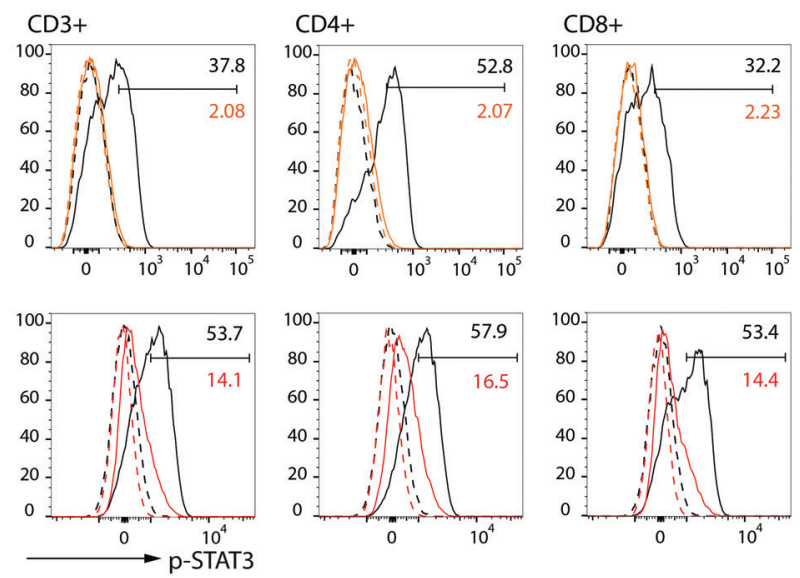

$-\mathrm{HD}+11-27$

- - - HD ctrl.

- p.P498L + IL -27

- - p.P498L ctrl.

C T Lymphoblasts

IL-6
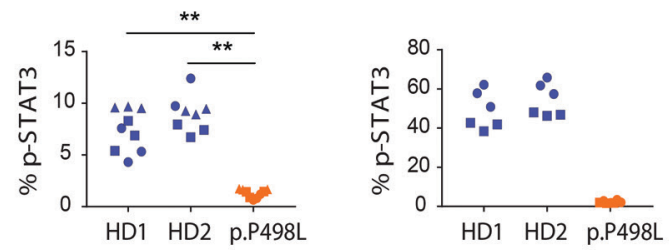

D

EBV-LCLS

IL-6

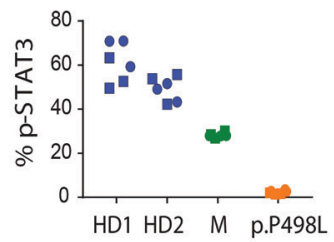

IL-21

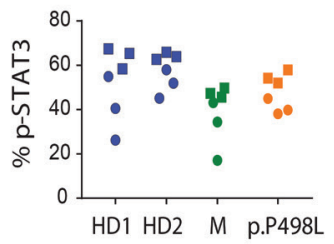

IL-10

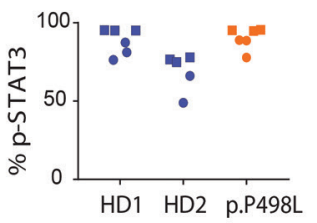

At 12 years of age, he developed an aphthous tongue ulcer suggestive of an undefined fungal lesion. No newtropenia was recorded, yet he benefited from granulocyte colony stimulating factor. He is currently under monthly intravenous immunoglobulin (IVIG) and cyclosporine A therapy.

Early after birth, the patient exhibited flexion contractures of the hand joints and presented with scaphocephaly (suggesting craniosynostosis) (Figure 1B) and ArnoldChari type 1 malformation. He has thoracolumbar scoliosis $\left(30^{\circ}\right)$ (Figure $1 \mathrm{~B}$ ), clubbing, crowded teeth and mild macroglossia. Cartilage destruction and erosion were seen
IL -21

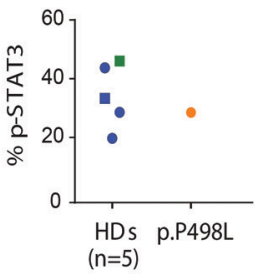

Figure 2. Functional assessment of GP130 $13498 \mathrm{~L}$ variant in primary cells. (A) Assessment of GP130 function by flow cytometry measuremont of percentage of p-STAT3 positive cells after stimulation of primary $\mathrm{T}$ cells with IL-6 (100 ng/mL), IL-27 (100 ng/mL), IL-10 (50 $\mathrm{ng} / \mathrm{mL})$ or IL-21 (100 mg/ mL) in $\mathrm{P}^{\mathrm{P} 498 \mathrm{~L}}$ (orange), mother of $\mathrm{P}^{\mathrm{p} 498 \mathrm{~L}}$ (green), and 4 healthy donors (HD: blue; age-matched HOs are represented by circles and adult HOs by squares). (B) Overlayed histograms showing shifts in p-STAT3 signal upon IL-27 stimulation (solid line) and baseline (dotted lines) in $\mathrm{CD}^{+}, \mathrm{CD}^{+}$and $\mathrm{CD}^{+}$ $\mathrm{T}$ cells of both $\mathrm{P}^{\mathrm{p} 498 \mathrm{~L}}$ (orange) and $\mathrm{P}^{\mathrm{N} 404 \mathrm{r}}$ (red) compared to a HD (black). Values represent percentage of p-STAT3 positive cells. (C and D) Percentage p-STAT3 assessed in (C) T lymphoblasts from $\mathrm{P}^{\mathrm{P} 498 \mathrm{~L}}$ and $2 \mathrm{HDs}$ and in (D) Epstein-Barr virus-transformed lymphoblastoid cell lines (EBV-LCLS) from $\mathrm{P}^{\mathrm{P} 498 \mathrm{~L}}$, mother of $\mathrm{P}^{\mathrm{P} 498 \mathrm{~L}}$ and 2 HD after stimulation with IL-6 (100 $\mathrm{ng} / \mathrm{mL}), \mathrm{IL}-10(50 \mathrm{ng} / \mathrm{mL}), \mathrm{IL}-21(100 \mathrm{ng} / \mathrm{mL})$, or IL-27 (100 mg/ mL). Data shown are from 2-3 independent experiments (shown by different data point shapes) with 2-3 replicates each. Statistical analysis on IL-6 stimulation of T lymphoblasts ( 3 independent experiments) was performed using an unpaired two-tailed Student $t$-test on the means of the technical replicates. $* * P<0.01, \mathrm{n}=3$.

IL -21

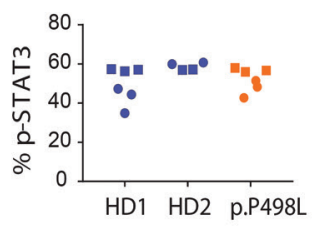

haematological | 2019; 104(3)

613 
during an operation for left hip dislocation at the age of 4 years. He subsequently developed right ankle edema, followed by progressive difficulty in walking and, finally, knee edema. He did not experience pain, erythema, or any increase in acute-phase reactants. The degeneration of the joints was classified as destructive arthropathy. In addition, the patient had neurodevelopmental delay of 1-2 years at the age of 4 years. $\mathrm{P}^{\mathrm{P} 49 \mathrm{LL}}$ showed consistently elevated serum IgE levels $(>2000 \mathrm{IU} / \mathrm{mL})$ and eosinophilia (Table 1). Progressive decline in absolute B-cell counts and low central memory $\mathrm{T}$ cells were observed (Table 1 and Figure 1C). These findings indicated a high National Institute of Health Hyper IgE syndromes (NIH HIES) score of 57 (Online Supplementary Table S2), raising suspicion of

Table 2. Comparative analysis of clinical features presenting in patients with IL6ST variants compared to other patient cohorts with defined gene defects.

\begin{tabular}{|c|c|c|c|c|c|c|c|c|c|c|}
\hline & $\begin{array}{l}\text { EP130 } \\
\text { defect } \\
(n=2)\end{array}$ & $\begin{array}{c}\text { STAT3 } \\
\text { HIES } \\
(n=140)^{47,48}\end{array}$ & $\begin{array}{c}\text { ZNF341 } \\
\text { deficiency } \\
(n=19)^{24,25}\end{array}$ & $\begin{array}{c}\text { DOCK8 } \\
\text { deficiency } \\
(n=64)^{49}\end{array}$ & $\begin{array}{l}\text { CARD11 } \\
\text { DN defect } \\
(n=12)^{50,51}\end{array}$ & $\begin{array}{c}\text { PGM3 } \\
\text { deficiency } \\
(n=29)^{52-54}\end{array}$ & $\begin{array}{l}\text { Loeys-Dietz } \\
\text { syndrome } \\
(n=8)^{55}\end{array}$ & $\begin{array}{l}\text { ERBDN } \\
(n=3)^{56}\end{array}$ & $\begin{array}{l}\text { Wiskott } \\
\text { Aldrich } \\
\text { syndrome } \\
\text { (incidence: } \\
\text { 1/250000) }\end{array}$ & $\begin{array}{c}\text { ARPC1b } \\
\text { defect } \\
(n=6)^{58-60}\end{array}$ \\
\hline Gene defect $t^{\mathrm{a}, \mathrm{b}}$ & $I L 6 S T$ & STAT3 & ZNF341 & DOCK8 & CARD11 & PGM3 & TGFBR1/TGFBR2 & ERBIN & WAS & $A R P C I B$ \\
\hline Inheritance & AR & $\mathrm{AD}$ & AR & AR & $\mathrm{AD}$ & AR & $\mathrm{AD}$ & $\mathrm{AD}$ & X-linked & AR \\
\hline $\operatorname{Ig} E^{c}$ & $\uparrow$ & $\uparrow \uparrow$ & $\uparrow \uparrow$ & $\uparrow$ & $\uparrow$ & $\uparrow \uparrow$ & $\uparrow \uparrow$ & $\uparrow$ & $\uparrow$ & $\uparrow$ \\
\hline Eosinophilia & + & + & $+/-$ & + & + & + & + & + & + & + \\
\hline Eczema & + & + & + & ++ & ++ & + & ++ & + & + & + \\
\hline $\begin{array}{l}\text { NIH HIES score } \\
\text { (typical) }^{d}\end{array}$ & $40-57$ & $>40$ & 11-62 & $20-40$ & ND & $27-55$ & ND & ND & ND & ND \\
\hline \multicolumn{11}{|l|}{ Infections } \\
\hline Abscess & $-1+$ & ++ & + & + & + & ++ & ++ & - & + & + \\
\hline Pneumonia & ++ & +++ & + & + & ++ & ++ & ++ & ++ & + & + \\
\hline Sinusitis/otitis & + & + & + & ++ & + & + & ++ & + & + & + \\
\hline Keratitis/ conjunctivitis & ++ & + & - & + & - & - & - & - & - & - \\
\hline Candidiasis & - & ++ & ++ & + & + & + & - & - & + & - \\
\hline Viral infections & - & + & - & +++ & + & ++ & - & - & + & + \\
\hline \multicolumn{11}{|c|}{ Parenchymal lung abnormalities } \\
\hline Bronchiectasis & ++ & ++ & + & + & + & + & + & - & + & + \\
\hline Pneumatocele & ++ & ++ & + & + & - & - & - & - & - & - \\
\hline
\end{tabular}

\begin{tabular}{|c|c|c|c|c|c|c|c|c|c|c|}
\hline \multicolumn{11}{|l|}{ Dysmorphia } \\
\hline Prominent forehead & ++ & ++ & + & + & + & + & - & - & - & - \\
\hline Cathedral palate & - & ++ & + & + & - & - & - & - & - & - \\
\hline Decidual teeth retention & ++ & ++ & + & + & $+/-$ & - & ++ & - & - & - \\
\hline Abnormal bone fractures & ++ & ++ & + & + & - & - & - & - & - & - \\
\hline $\begin{array}{l}\text { Craniosynostosis/ } \\
\text { abnormal skull shape }\end{array}$ & ++ & + & + & - & - & - & - & - & - & - \\
\hline Scoliosis & ++ & ++ & $+/-$ & + & $+/-$ & + & + & ++ & - & - \\
\hline Allergies & + & + & + & +++ & +++ & + & +++ & + & + & - \\
\hline Autoimmunity & - & + & - & ++ & + & ++ & - & - & ++ & + \\
\hline CNS involvement & ++ & + & + & ++ & - & ++ & - & - & - & - \\
\hline Neoplasia & - & + & $+/-$ & ++ & - & + & - & - & ++ & - \\
\hline \multicolumn{11}{|l|}{ Immunological features } \\
\hline $\begin{array}{l}\text { Immunoglobulins } \\
\text { (excluding IgE) }\end{array}$ & Normal & Normal & $\begin{array}{c}\text { Normal } \\
\text { / high IgG }\end{array}$ & $\begin{array}{l}\text { Normal } \\
\text { /low }\end{array}$ & $\begin{array}{c}\text { Normal } \\
\text { / low }\end{array}$ & Normal & Normal & Normal & $\begin{array}{c}\text { Variable } \\
\text { / high IgA }\end{array}$ & $\begin{array}{c}\text { Normal } \\
\text { / high IgA }\end{array}$ \\
\hline Lymphopenia & - & - & $+/-$ & $+/-$ & - & + & - & - & $+/-$ & - \\
\hline CD4 lymphopenia & - & - & $+/-$ & $+/-$ & - & + & - & - & $+/-$ & $-/+$ \\
\hline Th17 cells & Low & Low & Low & Low & Normal & Normal & Normal & Normal & Normal & ND \\
\hline CD19+ B cells & $\begin{array}{l}\text { Normal/ } \\
\text { low }\end{array}$ & $\begin{array}{l}\text { Normal/ } \\
\text { low }\end{array}$ & Normal & $\begin{array}{l}\text { Normal/ } \\
\text { low }\end{array}$ & $\begin{array}{c}\text { Normal/ } \\
\text { low }\end{array}$ & $\begin{array}{l}\text { Normal/ } \\
\text { low }\end{array}$ & Normal & Normal & $\begin{array}{c}\text { Normal/ } \\
\text { low }\end{array}$ & Normal \\
\hline $\begin{array}{l}\text { Switched-memory } \\
\text { B cells }\end{array}$ & $\begin{array}{l}\text { Normal/ } \\
\text { low }\end{array}$ & Low & Low & Low & $\begin{array}{c}\text { Normal/ } \\
\text { low }\end{array}$ & $\begin{array}{l}\text { Normal/ } \\
\text { low }\end{array}$ & Normal & Normal & $\begin{array}{c}\text { Normal/ } \\
\text { low }\end{array}$ & Normal \\
\hline
\end{tabular}

apart from STAT3 HIES, DOCK8 deficiency and WAS, the phenotypical comparisons have been made based on a limited number of published cases. Future studies and larger cohorts of patients will be needed to describe the full phenotypic spectrum of the individual disease entities. ${ }^{\text {TThere }}$ are additional gene defects that can present with high IgE, e.g. immune dysregulation polyendocrinopathy enteropathy X-linked (IPEX) syndrome due to FOXP3 defects. ${ }^{6}{ }^{\mathrm{c}} \uparrow \uparrow$ refers to IgE levels $>5000 \mathrm{IU} / \mathrm{mL} ; ~ \uparrow$ refers to IgE levels $1000-$ $5000 \mathrm{IU} / \mathrm{mL}$. ${ }^{d}$ The National Institute of Health Hyper-IgE syndromes (NIH HIES) score ${ }^{18}$ may be highly variable amongst individuals. The numbers indicated here represent ranges of values which are typically seen in the respective diseases; however, these should be taken with caution,in particular for those disease entities for which so far only a few individuals have been identified and described in the scientific literature. DN: dominant negative; ND: not determined; CNS: central nervous system. 
the autosomal dominant form of HIES, but capillary sequencing performed prior to whole exome sequencing did not reveal a mutation in STAT3. ${ }^{18}$ Family history was remarkable for the early death of 3 siblings (Figure 1A). The first female child (III-1 on Figure 1A) had scaphocephaly, foot deformities, recurrent diarrhea, respiratory infections, keratitis, and retarded growth and development. She died at the age of 3.5 years due to intestinal perforation. The second gestation resulted in twin brothers: III- 2 was born prematurely at 24 weeks with a foot deformity and died $2 \mathrm{~h}$ after birth, whereas III-3 died in utero at 20 weeks. The third gestation was P P4982.'s older brother (III4) who has congenital blindness, and the fourth was $P^{\mathrm{P} 448 \mathrm{~L}}$.

Patient $\mathrm{P}^{\mathrm{N} 404 \mathrm{Y}}$ bearing a GP130 $0^{\mathrm{N} 404 \mathrm{Y}}$ mutation has been described previously. ${ }^{5}$ The marked similarity of clinical phenotypes between $\mathrm{P}^{\mathrm{P} 49 \mathrm{~L} \mathrm{~L}}$ and $\mathrm{P}^{\mathrm{N} 404 \mathrm{Y}}$ is illustrated in Online Supplementary Table S3.

\section{Identification of a novel IL6ST mutation}

We performed whole exome sequencing in $\mathrm{P}^{\mathrm{P} 49 \mathrm{~L} \mathrm{~L}}$ to identify the underlying molecular disease etiology, and identified a homozygous missense mutation in IL6ST (c.1493C > T, p.P498L) (Figure 1D) deemed disease-causing based on functional predictions (Online Supplementary Table S4) and phenotypic similarity with the recently reported IL6ST-mutant (p.N404Y) patient, P P404Y ${ }^{5}$ These amino acid positions are within the fifth and fourth domains of GP130, respectively, forming crucial interactions with other residues to maintain the acute bend in the

\section{Fibroblasts}

A

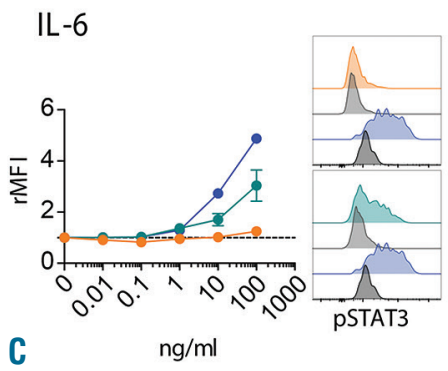

IL-27
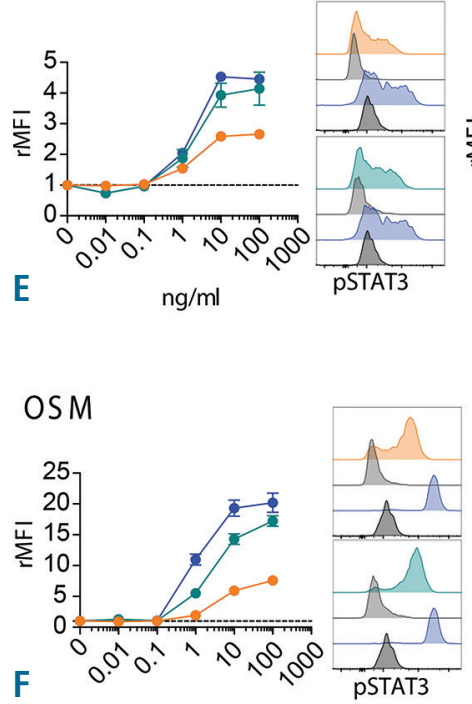

$\mathrm{ng} / \mathrm{ml}$

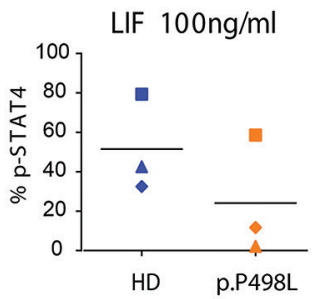

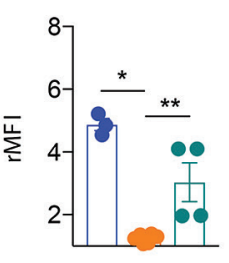

D
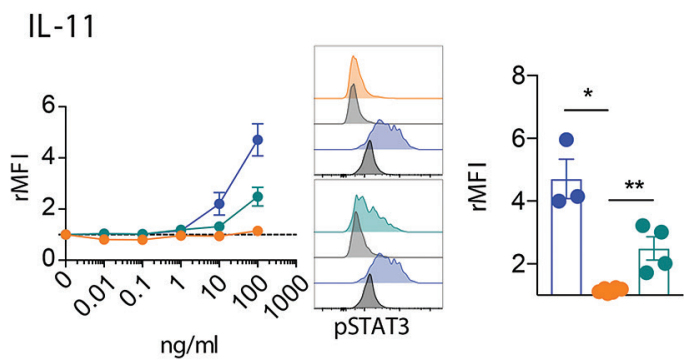

LIF

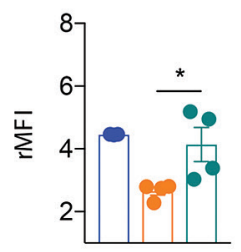

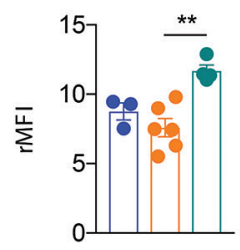

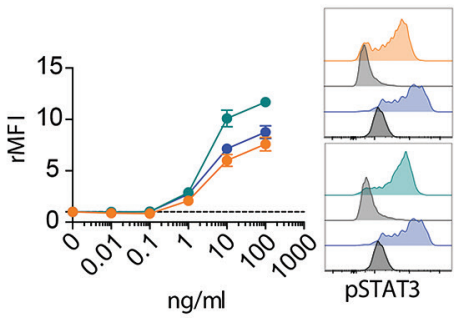

$\rightarrow H D$

- p.P498 L

$\rightarrow$ p.P498 L

+WT GP13 0 $\square$ p.P498L (Stim.)

$\square$ p.P498L

+WT GP130 (Stim.)

HD (Stim.)
p.P498L (Ctrl.)

p.P498L + WT GP130 (Ctrl.)

$\mathrm{HD}$ (Ctrl.)

Figure 3. Functional assessment of GP130 ${ }^{\text {P498L }}$ variant in fibroblasts. (A-E) Dose-escalation curves showing relative mean fluorescence intensity ( $\mathrm{MMFI}$ ) of $\mathrm{p}-\mathrm{STAT} 3$ after stimulation of $\mathrm{P}^{\mathrm{P} 498 \mathrm{~L}}$ and healthy donor (HD) fibroblasts as well as $P^{\text {P498L }}$ fibroblasts transduced with wild-type (WT) GP130 with (A) IL-6, (B) IL-11, (C) IL-27, (D) LIF, (E) OSM, following overnight starvation in serum-free media. Bar graphs (right) showing rMFI of fibroblasts upon stimulation with the highest concentration of the corresponding cytokine: 3 (HD), 6 (p.P498L) and 4 (p.P498L + WT GP130) replicates of 3 independent experiments; Mann-Whitney-test; $* P<0.05, * * P<0.01$. (F) Percentage of $p$-STAT4 assessed in $\mathrm{P}^{\mathrm{p} 498 \mathrm{~L}}$ and HD-derived fibroblasts after stimulation with LIF (100 ng/mL) following a 3-hour starvation in serumfree media. Three independent experiments were performed; the shapes of the symbols represent the individual experiments. 
protein structure that is conserved across species (Figure $1 \mathrm{E}$ and F). ${ }^{19}$ We found GP130 protein expressed in $\mathrm{P}^{\mathrm{P} 498 \mathrm{~L}}$ fibroblasts, albeit at lower levels (Figure 1G), and in a CRISPR-engineered HEK293-IL6ST knockout (KO) cell line with transient overexpression of the GP130 $0^{\mathrm{N} 404 \mathrm{Y}}$ mutant. ${ }^{5}$

\section{Functional assessment of GP130 ${ }^{\mathrm{P} 498 \mathrm{~L}}$ mutation in primary and patient-derived cells}

Phosphorylation of STAT3 ( $p$-STAT3) is a direct downstream effect of GP130 activation. To assess the impact of the p.P498L substitution, we studied STAT3 phosphorylation in primary $\mathrm{T}$ cells from $\mathrm{P}^{\mathrm{P} 498 \mathrm{~L}}$ and observed markedly decreased p-STAT3 levels upon stimulation with IL-6 and IL-27 compared to stimulation with IL-10 or IL-21 and to healthy donors (Figure 2A). Our previous study 5 on $\mathrm{P}^{\mathrm{N} 404 \mathrm{Y}}$ showed that IL- 6 signaling had been abolished but a smaller reduction in $\mathrm{p}$-STAT3 after stimulating primary $\mathrm{T}$ cells with IL-27 (CD3 ${ }^{+}, \mathrm{CD}^{+}$, and $\mathrm{CD}^{+} \mathrm{T}$ cells) (Figure $2 \mathrm{~B}$ ), indicating a mutation-dependent effect on the severity of downstream signaling through selected cytokines. Furthermore, IL-6 signaling was shown to be defective in both EBV-LCLs and T lymphoblasts derived from PBMCs of P P498L, and IL-27 (that stimulates T lymphoblasts) was aberrant in $\mathrm{P}^{\mathrm{P} 498 \mathrm{~L}}$ (Figure $2 \mathrm{C}$ and D). In addition, we tested the effect of the new p.P498L substitution on the activation of other STAT family transcription factors in T lymphoblasts. Stimulation with IL-6 mainly activated STAT3 in healthy donors with no compensatory increase in activation of STAT1 in the patient cells (Online Supplementary Figure S1A), whereas phosphorylation of STAT1, STAT3 and STAT4 was abolished in patient T lymphoblasts upon stimulation with IL-27 compared to healthy donor-derived cells (Online Supplementary Figure $S 1 B)$. Activation of STATs by GP130-independent cytokines including IL-4, IL-21 and IFN $\beta$ was unaffected in patient cells, except for STAT4 which showed increased phosphorylation upon IL-12 stimulation of $\mathrm{P}^{\mathrm{P} 498 \mathrm{~L}} \mathrm{~T}$ lymphoblasts (Online Supplementary Figure S1C-F).

To further evaluate the spectrum of mutation-dependent signaling defects, we analyzed p-STAT3 responses in fibroblasts from $\mathrm{P}^{\mathrm{P} 498 \mathrm{~L}}$ and a healthy donor, after overnight starvation. IL-6 or IL-11 stimulation demonstrated significantly reduced p-STAT3 levels (Figure $3 \mathrm{~A}$ and B), with the aberrant IL-11 signaling likely to underlie the majority of bone manifestations in $\mathrm{P}^{\text {P498L }} .{ }^{14}$ OSM stimulation resulted in a partial and statistically significant reduction in $\mathrm{p}$-STAT3

\section{HEK293T GP130 KO cell line}

A

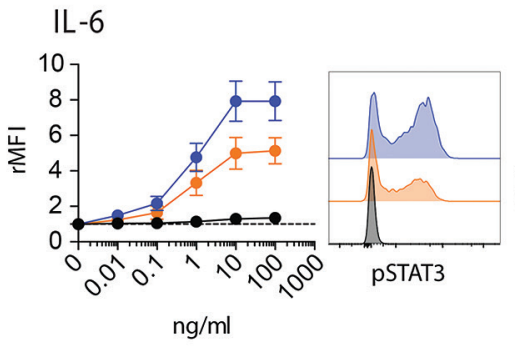

C

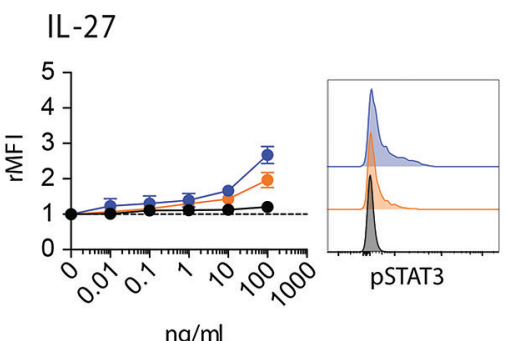

E

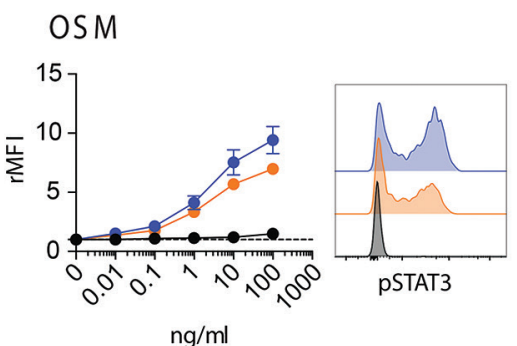

B
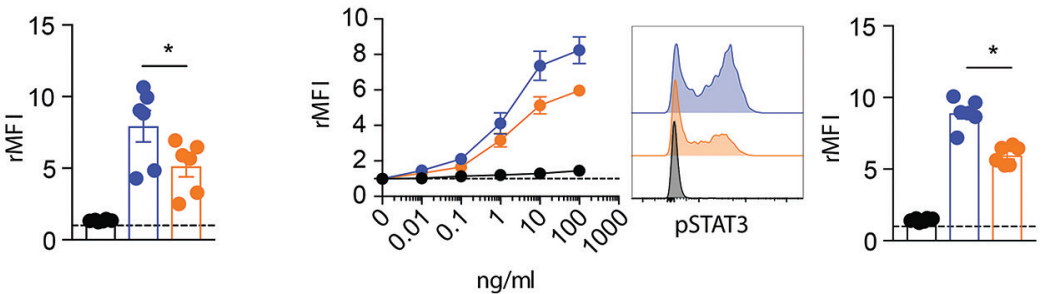

D
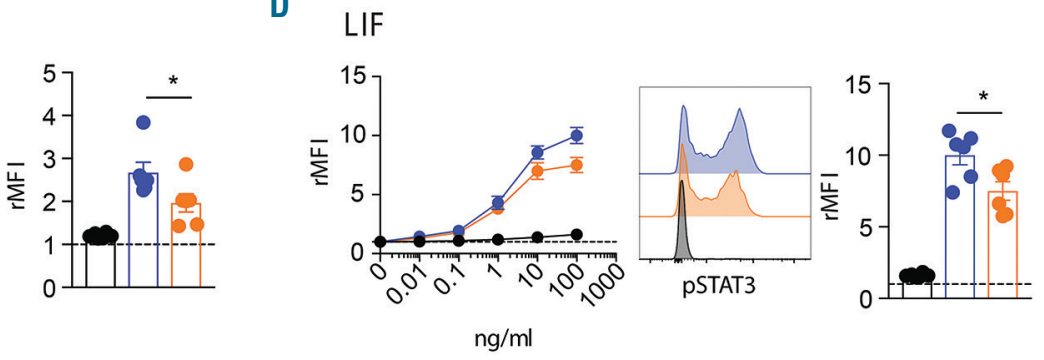

$\mathrm{ng} / \mathrm{ml}$

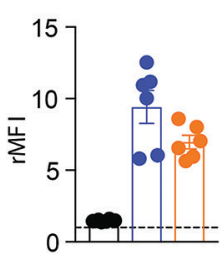

GP130 KO + p.P498L

GP130 KO + WT GP130

- WT GP13 0

$\mathrm{GP} 130 \mathrm{KO}+\mathrm{eV}$

Figure 4. Functional assessment of GP130 $1398 \mathrm{~L}$ variant in GP130-KO HEK293 cell line. (A-E) Relative mean fluorescence intensity (rMFI) of p-STAT3 in GP130 CRISPRknockout HEK293 cells that were transfected with a plasmid coding for the GP130 ${ }^{\text {p498 }}$ (GP130 KO + p.P498L), wild-type GP130 (GP130 KO + WT GP130) or transfected with the empty plasmid (GP130 KO + eV), after stimulation with (A) IL-6, (B) IL-11, (C) IL-27, (D) LIF, (E) OSM. From left to right: dose-escalation curves, stacked histograms displaying shifts in p-STAT3 signals, and bar graphs showing rMFI of fibroblasts upon stimulation with the highest concentration of the corresponding cytokine. (6 replicates of 3 independent experiments are shown; Wilcoxon matched-pairs signed rank test; *P<0.05.) 
responses in the patient-derived fibroblasts, whereas reductions in p-STAT3 upon LIF and IL-27 stimulation were not significant (Figure 3C-E). Unlike IL-27, LIF, and OSM, upon receptor binding, IL-6 and IL-11 form a hexameric complex requiring two GP130 proteins, possibly explaining the extremity of their disrupted signaling. Moreover, P ${ }^{\text {P498L's }}$ fibroblasts showed a reduced p-STAT1 response upon IL-27 or OSM treatment compared to healthy donor fibroblasts (Online Supplementary Figure S2). In addition to STAT3, stimulation of fibroblasts with LIF induces phosphorylation of STAT4 ${ }^{20}$ Interestingly, in $\mathrm{P}^{\mathrm{P} 498 \mathrm{~L}}$ fibroblasts, LIF-induced $\mathrm{p}$ STAT4 was slightly reduced when cells were starved in serum-free media for $3 \mathrm{~h}$ (Figure 3F). To demonstrate causality of the novel IL6ST mutation on the observed phenotype, we ectopically expressed WT-GP130 in GP130 ${ }^{\text {P498. }}$ fibroblasts. This rescued the defects in the IL- 6 and IL-11 signaling pathways and compensated the partial reductions in LIF, IL-27 and OSM signaling (Figure 3A-E). Finally, overexpression of GP130 ${ }^{\text {P498L }}$ in HEK293-IL6ST KO cells mirrored the defects observed in patient fibroblasts with significant reductions upon stimulation with IL-6, IL-11, IL-27 and LIF, while STAT3 phosphorylation in response to OSM was reduced but did not reach statistical significance $(P=0.0625)$ (Figure 4A-E).

\section{CD4 ${ }^{+} \mathrm{T}$-cells}

A

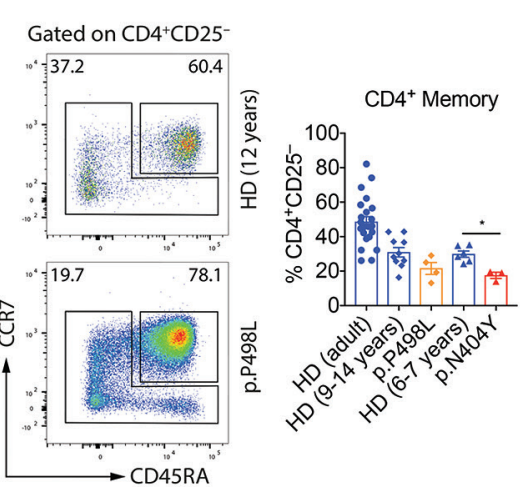

CD8 ${ }^{+}$-cells

D
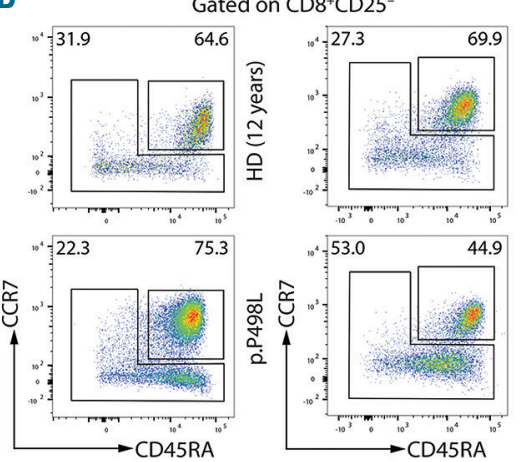

$\mathbf{F}$

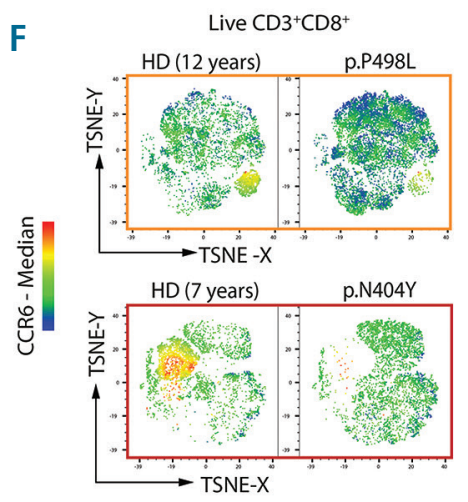

Gated on $\mathrm{CD}^{+} \mathrm{CD} 25^{-}$
B
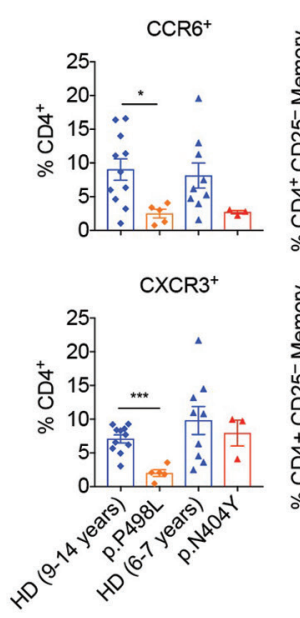
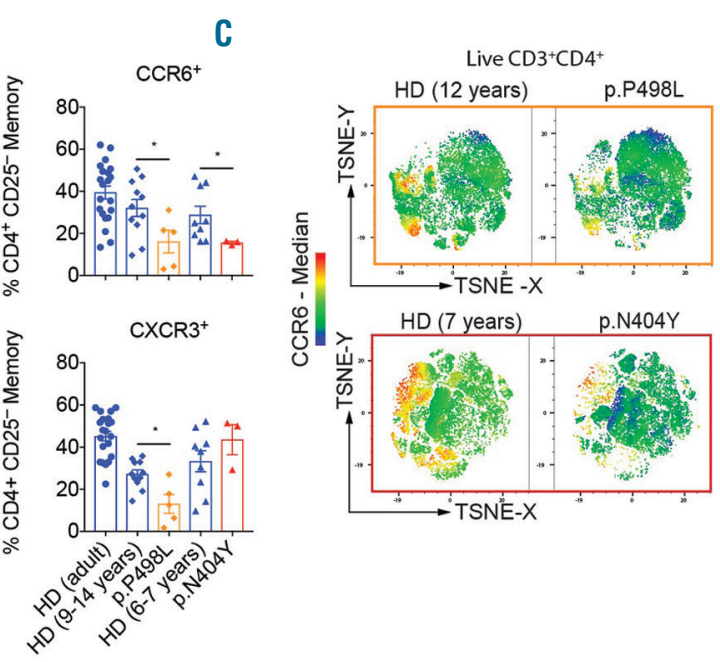

E

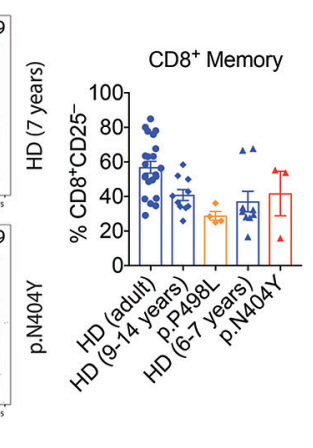

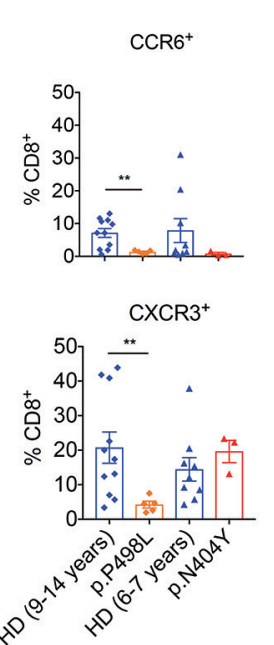
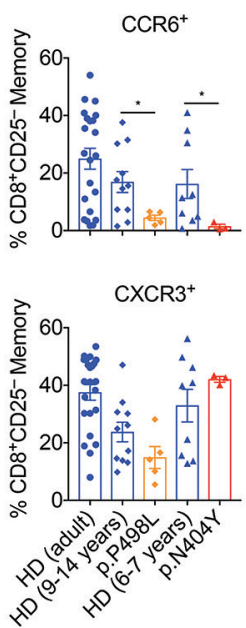

Figure 5. Phenotypic characterization of $\mathrm{CD}^{+}$and $\mathrm{CD}^{+} \mathrm{T}$-cell compartments. (A and D) Representative dot-plot and bar graph summary showing percentages of $(A) C D 4^{+}$and $(D) C D 8^{+}$naïve $\left(C D 45 R A^{+} C C R 7^{+}\right)$and memory [CD45RA-CCR7 ${ }^{+/}$including CD45RA ${ }^{+}$CCR7 ${ }^{-}$terminally differentiated effector memory (TEMRA)] cells shown as frequency of live $C D 3^{+} C D 4^{+} C D 25^{-}$or $C D 3^{+} C D 8^{+} C D 25^{-} \mathrm{T}$ cells, respectively. (B and $\mathrm{E}$ ) Bar graph summary showing $\mathrm{CXCR}^{+}$and $\mathrm{CCR} 6^{+}$frequencies of live (B) $\mathrm{CD}^{+} \mathrm{CD} 4^{+}$and $(\mathrm{E}) \mathrm{CD} 3^{+} \mathrm{CD} 8^{+}$cells, and as frequencies of live (B) $\mathrm{CD}^{+}{ }^{+} \mathrm{CD} 4^{+} \mathrm{CD} 25^{-}$and (E) CD3 ${ }^{+} \mathrm{CD} 8^{+} \mathrm{CD} 25^{-}$memory T cells. (C and F) t-Distributed Stochastic Neighbor Embedding (TSNE)-based analysis was performed on the following parameters: CD45RA, CD25, CD127, CCR4, CCR6, CCR7, CCR9, CCR10, CXCR3, CXCR5 and CRTh2. Overlaid heatmap statistics indicate median CCR6 expression in (C) live $\mathrm{CD}^{+}{ }^{+} \mathrm{CD} 4^{+} \mathrm{CD} 8^{-}$and $(\mathrm{F}) \mathrm{CD}^{+} \mathrm{CD} 8^{+} \mathrm{CD} 4^{-} \mathrm{T}$ cells. Bar graph summaries: mean+Standard Deviation: healthy donor (HD) (adult): $n=19$, HD age-matched controls (9-14 years): $n=10-11$, HD age-matched controls (6-7 years): $n=6$ 9. $P^{\text {P498L: }} n=5$ independent replicates from peripheral blood mononuclear cells (PBMCs) isolated at 3 distinct time points, seven and four months apart, $P^{\mathrm{N} 404 \mathrm{~V}}: \mathrm{n}=3$ replicates from 2 independent experiments and PBMCs taken two months apart. Mann-Whitney test, $* P<0.05 ; * * P<0.01 ; * * * P<0.001 ; * * * * P<0.0001$. Some HD control data shown have been published previously. ${ }^{5}$ 


\section{Effects of IL6ST mutations on T-cell differentiation and function}

As cells from $\mathrm{P}^{\mathrm{P} 498 \mathrm{~L}}$ and $\mathrm{P}^{\mathrm{N} 404 \mathrm{Y}}$ exhibited particularly aberrant IL-6 and IL-27 signaling, we hypothesized an impact on T-cell differentiation. Despite a history of recurrent infections, both patients had rather reduced $\mathrm{CD}^{+}$memory $\mathrm{T}$ cells and lower CCR6 expression in $\mathrm{CD}^{+}$memory $\mathrm{T}$ cells and total $\mathrm{CD}^{+} \mathrm{T}$ cells (particularly in $\mathrm{P}^{\mathrm{P} 498 \mathrm{~L}} ; P<0.05$ ) (Figure 5A and B and Online Supplementary Figure S3A and $B) .^{5}$ However, CXCR3 expression was reduced only in $\mathrm{CD} 4^{+} \mathrm{T}$ cells of $\mathrm{P}^{\mathrm{P} 498 \mathrm{~L}}$, while $\mathrm{CD} 4^{+}$memory $\mathrm{T}$ cells from $\mathrm{P}^{\mathrm{N} 404 \mathrm{Y}}$ showed increased expression of CCR4 and CRTh2. To investigate changes in Th-cell phenotypes, we analyzed chemokine receptor-expression linked to Th-cell homing and function. ${ }^{21,22}$ t-Distributed Stochastic Neighbor Embedding (TSNE) revealed that predominantly $\mathrm{CD}^{+}{ }^{+} \mathrm{CCR} 6^{+}$, but less so $\mathrm{CD} 4^{+}{ }^{+} \mathrm{CCR} 6^{-}$Th-cells, were reduced in both patients (Figure 5C). Moreover, although both patients showed normal numbers of total $\mathrm{CD}^{+}$ memory $\mathrm{T}$ cells (Figure 5D), CCR6 expression within $\mathrm{CD}^{+}$memory $\mathrm{T}$ cells was reduced (particularly in $\mathrm{P}^{\mathrm{P} 498 \mathrm{~L}}$; $P<0.05$ ) (Figure $5 \mathrm{E}$ and $\mathrm{F}$ and Online Supplementary Figure $S 3 C$ and $D$ ). Furthermore, both patients showed reduced frequencies of ROR $\mathrm{t}^{+}$(particularly in $\mathrm{P}^{\mathrm{P} 498 \mathrm{~L}} ; \mathrm{P}<0.05$ ) but not TBET ${ }^{+} \mathrm{CD}^{+} \mathrm{T}$ cells (Online Supplementary Figure S4A). The CD8 ${ }^{+} \mathrm{ROR} \gamma \mathrm{t}^{+}$memory T cells co-expressed CCR6 and intermediate level of TBET (Online Supplementary Figure $S 4 B$ and $C$ ). These results demonstrate that functional IL6 signaling in human $T$ cells is required for normal development of both CCR6-expressing $\mathrm{CD} 4^{+}$and $\mathrm{CD} 8^{+} \mathrm{T}$ cells. In addition, $\mathrm{P}^{\mathrm{P} 498 \mathrm{~L}}$ showed reduced $\mathrm{CD}^{+} \mathrm{CXCR}^{+}{ }^{+} \mathrm{T}$-cell frequencies (Figure 5E).

Both patients had normal frequencies of peripheral regulatory T cells (Online Supplementary Figure S5). However, in peripheral blood $\mathrm{CD}^{+}$memory cells, and more evidently in total $\mathrm{CD}^{+} \mathrm{T}$ cells, we noted reduced Th17enriched ${ }^{23}$ CCR $6^{+}$CCR4 $4^{+}$CXCR3- frequencies and lower Th1-enriched CCR6-CCR4-CXCR3 ${ }^{+}$frequencies only in $\mathrm{P}^{\mathrm{P} 498 \mathrm{~L}}$ (Figure 6A). On the other hand, Th2-enriched CCR6CCR $4^{+}$CXCR3- frequencies were significantly increased in $\mathrm{P}^{\mathrm{N} 404 \mathrm{Y}}$. To confirm chemokine receptor-based enrichments, and to evaluate also the composition of T-cell phenotypes inside chemokine receptor-enriched compartments, we analyzed subset specific transcription factor expression at the protein level (Online Supplementary Figure S6). TBET, GATA3 and RORyt expression fell into normal ranges, with elevated expression of GATA3 inside Th2 and Th17-enriched subsets of $\mathrm{P}^{\mathrm{N} 404 \mathrm{Y}}$ only (Online Supplementary Figure S7). Interestingly, at the functional level, $\mathrm{P}^{\mathrm{P} 498 \mathrm{~L}}$ showed reduced IL-17A-producing $\mathrm{CD}^{+}{ }^{+}$memory T-cell numbers. Furthermore, $\mathrm{P}^{\mathrm{P} 498 \mathrm{~L}}$ showed reduced IFN $\gamma$-producing and low IL-10-producing $(P=0.0667) \mathrm{CD}^{+}$ memory T-cell frequencies while IL-4 production was in the normal range (Figure 6B-E). Besides these aberrations in $\mathrm{CD}^{+} \mathrm{T}$ cells, $\mathrm{P}^{\mathrm{P} 498 \mathrm{~L}}$ had significantly less IFN $\gamma$-producing $\mathrm{CD}^{+}$memory $\mathrm{T}$ cells (Figure $6 \mathrm{~F}$ and $\mathrm{G}$ ) indicating that, in vivo, the IL-27-specific signaling defects shown to be more severe in $\mathrm{P}^{\mathrm{P} 498 \mathrm{~L}}$ affect both $\mathrm{CD} 4^{+}$and $\mathrm{CD}^{+} \mathrm{T}$-cell composition and effector function.

\section{Discussion}

In this study, we show an intriguingly high degree of phenotypic similarity between the clinical manifestations exhibited by 2 unrelated patients with cytokine selective IL6ST-loss of function mutations. Both patients present with elevated IgE, eosinophilia, recurrent infections (including invasive infections, severe lung pathology, and keratitis), and skeletal abnormalities (abnormal skull form/craniosynostosis and scoliosis). This is strikingly reminiscent of key features of HIES due to STAT3 variants or the recently studied ZNF341 deficiency, ${ }^{24,25}$ whereas they are less in common with other forms including DOCK8-deficiency ${ }^{26,27}$ and other deficiencies leading to high levels of serum $\operatorname{IgE}^{28}$ (Table 2). While STAT3 is a downstream transcription factor for several signaling pathways, including IL-10, IL-21 and IL-23, the mutations in IL6ST encoding GP130, constrict the defect to selected signaling pathways and suggest that defects in IL- 6 and IL11 signaling dominate the HIES phenotype, whereas additional defects in IL-27, LIF and OSM signaling might contribute to the individual immunopathology. The two mutations affecting GP130 (p.P498L and p.N404Y) are 95 amino acids apart, yet both are on the highly conserved membrane-proximal ectodomain of the protein, known to play a crucial role in signal transduction and downstream JAK activation. ${ }^{29-31}$ Both variants show stable GP130 surface expression, preserving a partially intact quaternary protein structure, allowing GP130 to bind its ligands, and maintaining downstream signaling of cytokines such as LIF.

The effect of individual GP130 variants may depend on various factors, including the genetic variant itself, the cytokine levels, as well as GP130 expression and receptor/co-receptor stochiometries in different cell types, explaining the cell type specific responses. We have addressed these factors by plasmid transfection combined with cytokine stimulation assays that cover a range of concentrations, as well as by comparing diverse types of primary immune cells. We found that the GP130 $0^{\text {P4982 }}$ variant has a significant impact on IL-6, IL-11, IL-27 and LIF signaling in the HEK293 transfection assay and impaired downstream signaling upon stimulation with IL-6 and IL27 in primary T cells, T lymphoblasts and EBV-LCLs, as well as IL-6 and IL-11 in fibroblasts. Yet, in fibroblasts, signaling upon OSM (and to some extent IL-27 and LIF) stimulation was reduced but not completely abrogated. STAT1 that was phosphorylated in response to IL-27 and OSM in healthy donor fibroblasts showed decreased phosphorylation in P P498L fibroblasts. Furthermore, in response to IL-27, STAT1, STAT3 and STAT4 phosphorylation was compromised in T lymphoblasts of $\mathrm{P}^{\text {p4982 }}$, demonstrating a general defect in signal transduction.

IL-6 is a key cytokine responsible for the activation and differentiation of both $\mathrm{T}$ and $\mathrm{B}$ cells, as well as pro-inflammatory cues, including the acute-phase response. ${ }^{12}$ Therefore, the absence of an IL-6 response in $\mathrm{P}^{\mathrm{P} 498 \mathrm{~L}}$ explains his high susceptibility to pulmonary infections with no fevers. In contrast, aberrant IL-11 signaling underlies the observed bone manifestations in both patients with supporting evidence from IL11RA-deficient patients that present with craniosynostosis and delayed tooth eruption. ${ }^{14,15}$ IL-27 promotes differentiation of $\mathrm{CD} 4^{+} \mathrm{T}$ cells towards the Th1 phenotype, promotes IFN $\gamma^{+} \mathrm{IL}-10^{+} \mathrm{FOXP3}-\mathrm{T}$-helper cell differentiation, and enhances $\mathrm{CD} 8^{+} \mathrm{T}$-cell responses by increasing proliferation and effector functions such as IFNy production and cytolytic activity. ${ }^{13,32-36}$ Defects in these immune functions were particularly seen in $\mathrm{P}^{\mathrm{P} 498 \mathrm{~L}}$ who had completely aberrant IL-27 signaling in primary $\mathrm{T}$ 
A
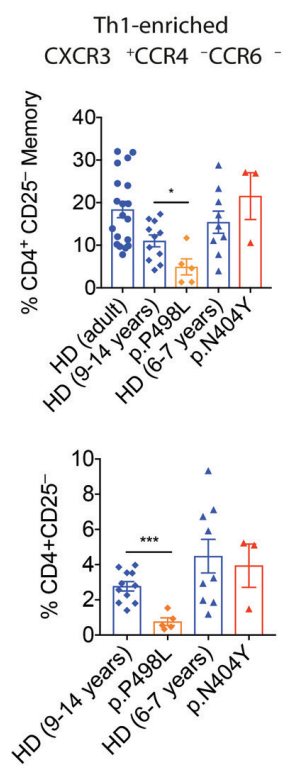

Th2-enriched CCR4 ${ }^{+}$CXCR3 - CCR6
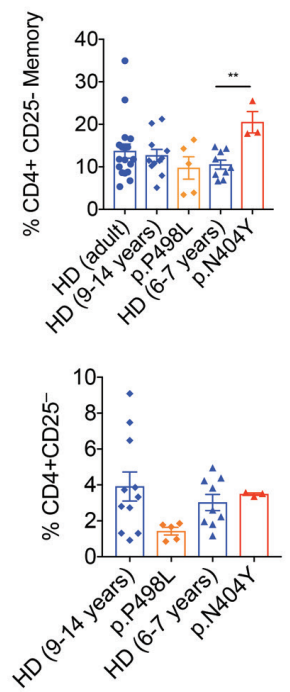

D

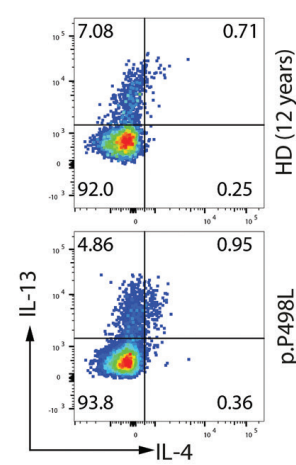

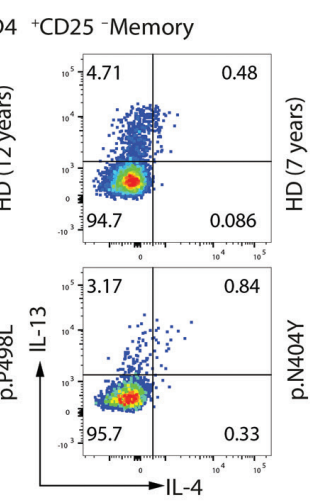

$\mathrm{F}$
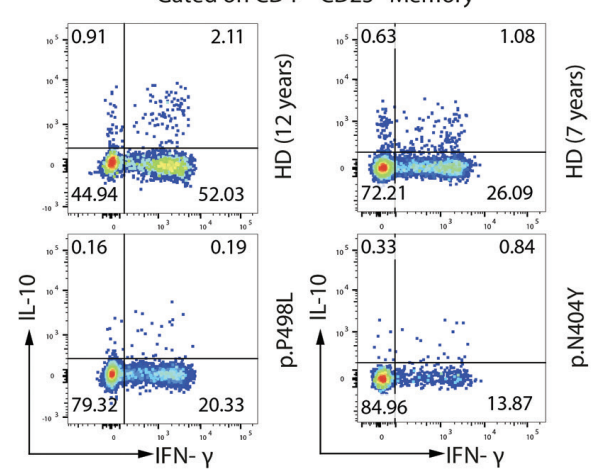

H

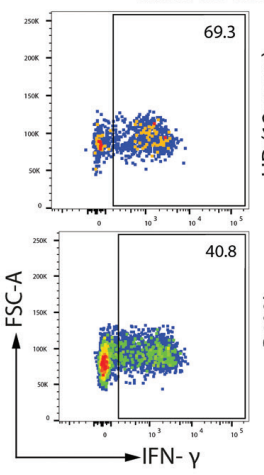

Th17-enriched CCR6 ${ }^{+} \mathrm{CCR} 4+{ }^{+} \mathrm{CXCR3}$
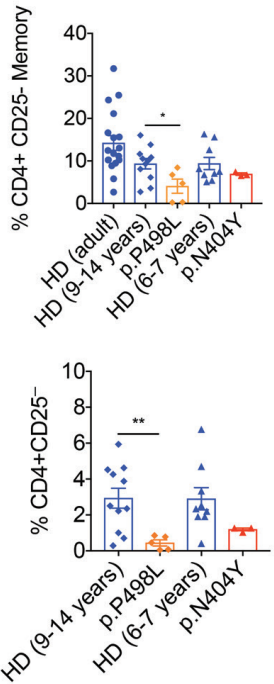

E

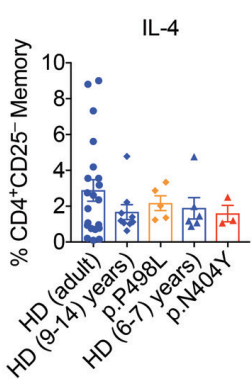

G

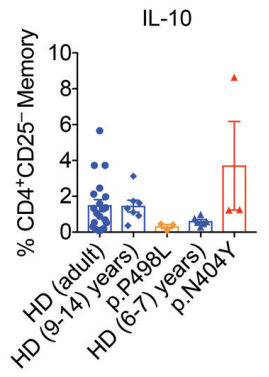

I

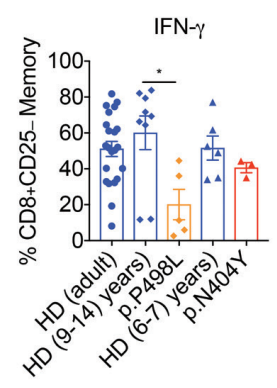

C

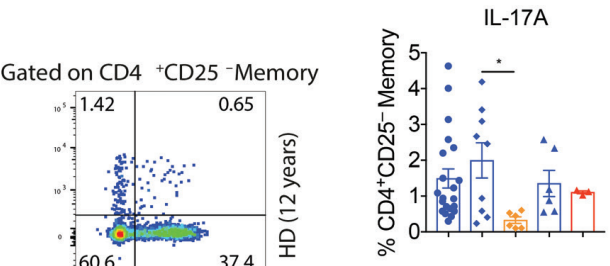

IFN- $\gamma$

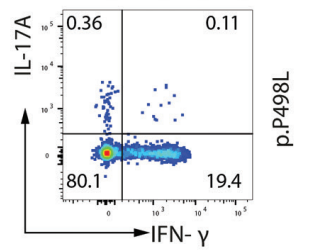

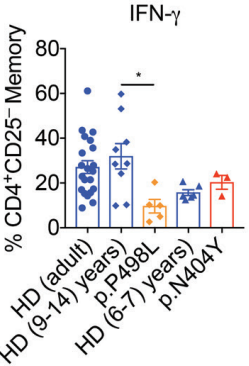

Figure 6. Functional characterization of $\mathrm{CD}^{+}$and $\mathrm{CD}^{+} \mathrm{T}$ cells with transcription factor expression analysis. (A) Flow cytometry analysis of frequencies of Th-cell subtype-enriched compartments based on chemokine receptor expression as percent of live $\mathrm{CD}^{+}{ }^{+} \mathrm{CD} 4^{+} \mathrm{CD} 25^{-} \mathrm{T}$ cells or $\mathrm{CD} 3^{+} \mathrm{CD} 4^{+} \mathrm{CD} 25^{-}$memory $\mathrm{T}$ cells: $\quad \mathrm{CXCR}^{+}{ }^{+} \mathrm{CR} 4^{-} \mathrm{CCR}^{-} \quad$ (Th1-enriched), CCR4 ${ }^{+}$CXCR3 ${ }^{-}$CCR6 ${ }^{-}$(Th2-enriched) and $\mathrm{CCR}^{+}{ }^{+} \mathrm{CCR}^{+}{ }^{+} \mathrm{CXCR}^{-}$(Th17-enriched). (B and C) Dotplot presentation $(B)$ and summary $(C)$ of intracellular cytokine staining (ICCS) for IFN- $\gamma$ and IL-17A shown as percent of live $\mathrm{CD}^{+} \mathrm{CD} 4^{+} \mathrm{CD} 25^{-}$memory $\mathrm{T}$ cells from $\mathrm{P}^{\text {P498L }}$ ( $(\mathrm{D}$ and $\mathrm{E}$ ) Dot-plot presentation (D) and summary (E) of ICCS for IL-4 and/or IL-13 shown as percent of live $\mathrm{CD}^{+}{ }^{+} \mathrm{CD} 4^{+} \mathrm{CD} 25^{-}$memory $\mathrm{T}$ cells from $\mathrm{P}^{\mathrm{P} 498 \mathrm{~L}}$ and $\mathrm{P}^{\mathrm{N} 404 \mathrm{Y}}$. ( $\mathrm{F}$ and $\mathrm{G}$ ) Dot-plot presentation $(\mathrm{F})$ and summary (G) of ICCS for IFN- $\gamma$ and/or IL-10 shown as percent of live $\mathrm{CD}^{+} \mathrm{CD} 4^{+} \mathrm{CD} 25^{-}$memory $\mathrm{T}$ cells from $\mathrm{P}^{\mathrm{P} 498 \mathrm{~L}}$ and $\mathrm{P}^{\mathrm{N} 404 \mathrm{r}}(\mathrm{H}$ and $\mathrm{I})$ Dot-plot presentation $(\mathrm{H})$ and summary (I) of ICCS for IFN- $\gamma$ shown as percent of live $\mathrm{CD}^{+}{ }^{+} \mathrm{CD} 8^{+} \mathrm{CD} 25^{-}$memory $T$ cells from $\mathrm{P}^{\mathrm{P} 498 \mathrm{~L}}$ and $\mathrm{P}^{\mathrm{N} 404 \mathrm{Y}}$ Bar graph summaries: mean+Standard Deviation (SD): healthy donor (HD) (adult): $n=19$, HD agematched controls (9-14 years): $n=7-11$, HD agematched controls (6-7 years): $n=6-9, P^{\text {p498L }}: n=5$ inde pendent replicates from peripheral blood mononuclear cells (PBMCs) isolated at 3 distinct time points, seven and four months apart, $\mathrm{P}^{\mathrm{N} 404 \mathrm{r}} \mathrm{n}=3$ replicates from 2 independent experiments and PBMCs taken five months apart. Mann-Whitney test; $\star P<0.05$; $* * P<0.01 ; * * * P<0.001 ; * * * * P<0.0001$. Some HD control data shown have been published previously. ${ }^{5}$ 
cells and $\mathrm{T}$ lymphoblasts compared to $\mathrm{P}^{\mathrm{N} 404 \mathrm{Y}}$ who had some retained signaling.

To investigate the effects of aberrant GP130 signaling pathways on $\mathrm{T}$ cells, we aimed to characterize T-cell phenotype and function in $\mathrm{P}^{\mathrm{P} 498 \mathrm{~L}}$ and $\mathrm{P}^{\mathrm{N} 404 \mathrm{Y}}$. Both patients had low $\mathrm{CD}^{+} \mathrm{CCR} 6^{+} \mathrm{T}$ cells. $\mathrm{CD} 8^{+} \mathrm{CCR} 6^{+} \mathrm{T}$ cells coexpressed ROR $\gamma$ t and intermediate level of TBET reminiscent of non-conventional $\mathrm{CD} 8^{+} \mathrm{T}$ cells, including mucosal-associated invariant $\mathrm{T}$ cells (MAIT cells) that are enriched in the $\mathrm{CD}_{161^{+}}$and $\mathrm{CCR} 6^{+}$fraction of $\mathrm{CD} 8^{+} \mathrm{T}$ cells and express a high level of RORyt but an intermediate level of TBET. ${ }^{37-39}$ These data support previous observations of the critical role of STAT3 signaling for the development of non-conventional $\mathrm{T}$ cells including MAIT cells ${ }^{36}$ In addition, both patients presented with low CCR ${ }^{+}$CCR 4 ${ }^{+}$CXCR3 ${ }^{-}$Th17-enriched T cells and IL$17 \mathrm{~A}$ production that were more prominent in $\mathrm{P}^{\mathrm{P} 498 \mathrm{~L}}$, possibly explaining the development of a tongue fungal lesion only in $\mathrm{P}^{\text {P4982. }}$. Reminiscent of low Th17 cells and IL$17 \mathrm{~A}$ production in HIES patients, ${ }^{24,40-42}$ these findings highlight the importance of IL-6 in the development of CCR6-expressing and IL-17A-producing human Th-cells despite the presence of functional IL-1 $\beta$, IL-23 and IL-21 signaling pathways that are critical for human Th17 differentiation. ${ }^{43,44}$ While reduced $\mathrm{CD} 8{ }^{+} \mathrm{CCR} 6^{+} \mathrm{T}$ cell and Th17 cell frequencies are common to both patients, we also identified non-shared phenotypic aberrations. $\mathrm{P}^{\mathrm{N} 404 \mathrm{Y}}$ showed increased Th2 frequencies similar to that observed in STAT3 and DOCK8-deficient patients. The $\mathrm{P}^{\mathrm{N} 404 \mathrm{Y}}$ patient also presented with greater GATA3 expression in both Th2 and Th17-enriched subsets, pointing towards a Th2-biased polarization to the detriment of classical Th1 and Th17 cells. On the other hand, P P498L showed lower CXCR3 expression with reduced CCR6-CCR4-CXCR3 ${ }^{+}$Th1-enriched T cells and low IFN $\gamma$ production by $\mathrm{CD} 4^{+}$and $\mathrm{CD} 8^{+}$memory $\mathrm{T}$ cells. This can also be compared to STAT3 LOF patients with normal levels of Th1 cells with a defective IL-27/STAT3 axis but functional IL-27/STAT1 axis, leading to a normal IFNy response upon IL-27 stimulation. ${ }^{45}$ Hence, we speculate that the characteristic $\mathrm{T}$-cell features of $\mathrm{P}^{\mathrm{P} 498 \mathrm{~L}}$ might be due to complete loss of IL-27 signaling that has been shown to play a role in Th1 and $\mathrm{CD} 8^{+}$T-cell memory development and effector responses.

In summary, by characterizing a novel mutation in
IL6ST and comparing phenotypic and functional features of patients with two independent mutations, we define IL-6 and IL-11 signaling as the dominant defects in GP130/STAT3 HIES. Our data suggest that a shared GP130-STAT3 signaling module is the functional basis of the striking phenotypic similarities of patients with pathogenic IL6ST and STAT3 variants. IL-6 signaling plays a critical role in vivo in the development of human $\mathrm{CD} 4^{+} \mathrm{CCR} 6{ }^{+}$helper $\mathrm{T}$ cells including Th17 and contributes to the development of human $\mathrm{CD}^{+} \mathrm{CCR} 6^{+} \mathrm{T}$ cells. The discovery of two IL6ST non-synonymous mutations among hundreds of patients with overlapping immune and skeletal problems supports a model whereby only a limited number of non-synonymous combinatorial defects that affect selected signaling cascades are viable, despite severe systemic pathology due to embryological effects, but have sufficient pathogenicity to drive an immunopathology of combined immunodeficiency, elevated IgE levels, and skeletal anomalies.

\section{Acknowledgments}

We are grateful to all patients, their families and the healthy donors who have given their blood samples for this study. We also thank the nurses including Feride Özkan, Meliha Erol. We are grateful that Tatjana Hirschmugl and Raúl Jiménez Heredia and Jasmin Dmytrus performed exome sample preparation and assisted in data interpretation. We acknowledge the contribution of the Oxford Gastrointestinal Illness Biobank, which is supported by the NIHR Biomedical Research Centre, Oxford.

\section{Funding}

Supported by an ERC Starting grant (agreement 310857), the Austrian Science Fund (FWF): Project P 29951-B30, a doctoral fellowship program (Cell Communication in Health and Disease (CCHD) from the Medical University of Vienna (all to KB), the contribution of the Oxford Gastrointestinal biobank, which is supported by the NIHR Oxford Biomedical Research Centre, the Leona M. and the Harry B. Helmsley Charitable Trust (to $H H U)$, the Department of Health, UK, Quality, Improvement, Development and Initiative Scheme (grant to $A O M W$ ), the Wellcome Trust (project grant 093329 to AOMW and SRFT), Investigator Award 102731 and grant 090532/Z/09/Z supporting the Wellcome Trust Centre for Human Genetics both to $A O M W$ and the Deutsche Forschungsgemeinschaft (grant SCHW1730/1-1 to TSc).

\section{References}

1. Grimbacher B, Holland SM, Gallin JI, et al. Hyper-IgE Syndrome with Recurrent Infections - An Autosomal Dominant Multisystem Disorder. N Engl J Med. 1999; 340(9):692-702

2. Grimbacher B, Holland SM, Puck JM. Hyper-IgE syndromes. Immunol Rev. 2005; 203(1):244-250.

3. Holland SM, DeLeo FR, Elloumi HZ, et al. STAT3 Mutations in the Hyper-IgE Syndrome. N Engl J Med. 2007;357(16): 1608-1619

4. Minegishi Y, Saito M, Tsuchiya S, et al. Dominant-negative mutations in the DNAbinding domain of STAT3 cause hyper-IgE syndrome. Nature. 2007;448(7157):10581062.

5. Schwerd T, Twigg SRF, Aschenbrenner D, et al. A biallelic mutation in IL6ST encoding the GP130 co-receptor causes immunodeficiency and craniosynostosis. J Exp Med. 2017;214(9):2547-2562.

6. O'Shea JJ, Plenge R, Mohseni M, et al. JAK and STAT signaling molecules in immunoregulation and immune-mediated disease. Immunity. 2012;36(4):542-550.

7. Yoshida K, Taga T, Saito M, et al. Targeted disruption of gp130, a common signal transducer for the interleukin 6 family of cytokines, leads to myocardial and hematological disorders. Proc Natl Acad Sci U S A. 1996;93(1):407-411

8. Betz UA, Bloch W, van den Broek M, et al. Postnatally induced inactivation of gp130 in mice results in neurological, cardiac, hematopoietic, immunological, hepatic, and pulmonary defects. J Exp Med. 1998; 188(10):1955-1965.
9. Kopf M, Baumann H, Freer G, et al. Impaired immune and acute-phase responses in interleukin-6-deficient mice. Nature. 1994:368(6469):339-342.

10. van der Poll T, Keogh C V, Guirao X, Buurman WA, Kopf M, Lowry SF. Interleukin-6 gene-deficient mice show impaired defense against pneumococcal pneumonia. J Infect Dis. 1997;176(2):439444.

11. Puel A, Picard C, Lorrot M, et al. Recurrent staphylococcal cellulitis and subcutaneous abscesses in a child with autoantibodies against IL-6. J Immunol 2008;180(1):647-54.

12. Hunter CA, Jones SA. IL-6 as a keystone cytokine in health and disease. Nat Immunol. 2015;16(5):448-457.

13. Yoshida H, Hunter CA. The Immunobiology of Interleukin-27. Annu Rev Immunol. 2015;33:417-443. 
14. Keupp K, Li Y, Vargel I, et al. Mutations in the interleukin receptor IL11RA cause autosomal recessive Crouzon-like craniosynostosis. Mol Genet Genomic Med. 2013;1(4):223-237.

15. Nieminen P, Morgan NV, Fenwick AL, et al. Inactivation of IL11 Signaling Causes Craniosynostosis, Delayed Tooth Eruption, and Supernumerary Teeth. Am J Hum Genet. 2011;89(1):67-81.

16. Escary J-L, Perreau J, Duménil D, Ezine S, Brûlet P. Leukaemia inhibitory factor is necessary for maintenance of haematopoietic stem cells and thymocyte stimulation. Nature. 1993;363(6427):361-364

17. Masu Y, Wolf E, Holtmann B, Sendtner M, Brem G, Thoenen H. Disruption of the CNTF gene results in motor neuron degeneration. Nature. 1993:365(6441):27-32.

18. Grimbacher B, Schäffer AA, Holland SM, et al. Genetic linkage of hyper-IgE syndrome to chromosome 4. Am J Hum Genet. 1999; 65(3):735-744.

19. Xu Y, Kershaw NJ, Luo CS, et al. Crystal structure of the entire ectodomain of gp130: insights into the molecular assembly of the tall cytokine receptor complexes. J Biol Chem. 2010;285(28):21214-21218.

20. Nguyen HN, Noss EH, Mizoguchi F, et al. Autocrine loop involving IL-6 family member LIF, LIF receptor, and STAT4 drives sustained fibroblast production of inflammatory mediators. Immunity. 2017; 46(2):220-232.

21. Sallusto F, Lanzavecchia A. Heterogeneity of $\mathrm{CD} 4+$ memory $\mathrm{T}$ cells: functional modules for tailored immunity. Eur J Immunol. 2009:39(8):2076-2082.

22. Brodie T, Brenna E, Sallusto F. OMIP-018: Chemokine receptor expression on human T helper cells. Cytometry A. 2013; 83A(6):530-532.

23. Acosta-Rodriguez EV, Rivino L, Geginat J, et al. Surface phenotype and antigenic specificity of human interleukin 17-producing $\mathrm{T}$ helper memory cells. Nat Immunol. 2007:8(6):639-646

24. Béziat V, Li J, Lin J-X, et al. A recessive form of hyper-IgE syndrome by disruption of ZNF341-dependent STAT3 transcription and activity. Sci Immunol. 2018;3(24): eaat4956.

25. Frey-Jakobs S, Hartberger JM, Fliegauf M, et al. ZNF341 controls STAT3 expression and thereby immunocompetence. Sci Immunol. 2018;3(24).

26. Zhang Q, Davis JC, Lamborn IT, et al. Combined Immunodeficiency Associated with DOCK8 Mutations. N Engl J Med. 2009:361(21):2046-2055

27. Engelhardt KR, McGhee S, Winkler S, et al. Large deletions and point mutations involving the dedicator of cytokinesis 8 (DOCK8) in the autosomal-recessive form of hyperIgE syndrome. J Allergy Clin Immunol. 2009;124(6):1289-1302.e4.

28. Zhang $\mathrm{Q}$, Boisson B, Béziat V, Puel A, Casanova J-L. Human hyper-IgE syndrome: singular or plural? Mamm Genome. 2018;29(7-8):603-617

29. Kurth I, Horsten U, Pflanz S, et al. Importance of the membrane-proximal extracellular domains for activation of the signal transducer glycoprotein 130 . J Immunol. 2000;164(1):273-282.

30. Hammacher A, Wijdenes J, Hilton DJ, Nicola NA, Simpson RJ, Layton JE. Ligandspecific utilization of the extracellular membrane-proximal region of the gp130-related signalling receptors. Biochem J. 2000;345 Pt
1(Pt 1):25-32.

31. Timmermann A, Küster A, Kurth I, Heinrich PC, Müller-Newen G. A functional role of the membrane-proximal extracellular domains of the signal transducer gp130 in heterodimerization with the leukemia inhibitory factor receptor. Eur J Biochem. 2002;269(11):2716-2726.

32. Yoshimura T, Takeda A, Hamano S, et al. Two-sided roles of IL-27: induction of Th1 differentiation on naive CD4+ $\mathrm{T}$ cells versus suppression of proinflammatory cytokine production including IL-23-induced IL-17 on activated CD4+ T cells partially through STAT3-dependent mechanism. I Immunol. 2006;177(8):5377-5385.

33. Schneider R, Yaneva T, Beauseigle D, ElKhoury L, Arbour N. IL-27 increases the proliferation and effector functions of human naïve CD8+ T lymphocytes and promotes their development into Tc1 cells. Eur Immunol. 2011;41(1):47-59.

34. Kamiya YS, Mizuguchi J, Morishima TN, et al. Generation with enhanced granzyme B T cell + augmentation of effector CD8 augmentation of effector CD8 T cell generation with enhanced granzyme $\mathrm{B}$ expression by IL-27 1. J Immunol. 2005; 17516861751693

35. Owaki T, Asakawa M, Morishima N, et al. STAT3 is indispensable to IL-27-mediated cell proliferation but not to IL-27-induced Th1 differentiation and suppression of proinflammatory cytokine production. J Immunol. 2008;180(5):2903-2911.

36. Batten M, Kljavin NM, Li J, Walter MJ, de Sauvage FJ, Ghilardi N. Cutting edge: IL-27 is a potent inducer of IL-10 but not FoxP3 in murine T cells. J Immunol. 2008, 180(5):2752-2756

37. Wilson RP, Ives ML, Rao G, et al. STAT3 is a critical cell-intrinsic regulator of human unconventional $\mathrm{T}$ cell numbers and function. J Exp Med. 2015;212(6):855-864.

38. Turtle CJ, Delrow J, Joslyn RC, et al. Innate signals overcome acquired TCR signaling pathway regulation and govern the fate of human CD161(hi) CD8 + semi-invariant T cells. Blood. 2011:118(10):2752-2762.

39. Dias J, Sandberg JK, Leeansyah E. Extensive phenotypic analysis, transcription factor profiling, and effector cytokine production of human MAIT Cells by flow cytometry. Methods Mol Biol. 2017;1514:241-56

40. Ma CS, Chew GYJ, Simpson N, et al. Deficiency of Th17 cells in hyper IgE syndrome due to mutations in STAT3. J Exp Med. 2008;205(7):1551-1557.

41. Tangye SG, Pillay B, Randall KL, et al. Dedicator of cytokinesis 8-deficient CD4 + $\mathrm{T}$ cells are biased to a T H 2 effector fate at the expense of T H 1 and T H 17 cells. J Allergy Clin Immunol. 2017;139(3):933-49.

42. Keles S, Charbonnier LM, Kabaleeswaran V, et al. Dedicator of cytokinesis 8 regulates signal transducer and activator of transcription 3 activation and promotes TH17 cell differentiation. J Allergy Clin Immunol. 2016;138(5):1384-1394.e2.

43. Zhou L, Ivanov II, Spolski R, et al. IL-6 programs TH-17 cell differentiation by promoting sequential engagement of the IL-21 and IL-23 pathways. Nat Immunol. 2007;8(9): 967-974.

44. Korn T, Bettelli E, Gao W, et al. IL-21 initiates an alternative pathway to induce proinflammatory TH17 cells. Nature. 2007;448(7152):484-487.

45. Ma CS, Avery DT, Chan A, et al. Functional
STAT3 deficiency compromises the generation of human $\mathrm{T}$ follicular helper cells. Blood. 2012;119(17):3997-4008.

46. Morbach H, Eichhorn EM, Liese JG Girschick HJ. Reference values for B cell subpopulations from infancy to adulthood. Clin Exp Immunol. 2010;162(2):271-279.

47. Chandesris M-O, Melki I, Natividad A, et al. Autosomal Dominant STAT3 Deficiency and Hyper-IgE Syndrome. Medicine (Baltimore). 2012;91(4):e1-e19.

48. Gernez Y, Freeman AF, Holland SM, et al Autosomal Dominant Hyper-IgE Syndrome in the USIDNET Registry. J allergy Clin Immunol Pract. 2018;6(3):996-1001.

49. Engelhardt KR, Gertz ME, Keles S, et al. The extended clinical phenotype of 64 patients with dedicator of cytokinesis 8 deficiency. Allergy Clin Immunol. 2015;136(2):402-412.

50. Dadi H, Jones TA, Merico D, et al Combined immunodeficiency and atopy caused by a dominant negative mutation in caspase activation and recruitment domain family member 11 (CARD11). J Allergy Clin Immunol. 2018;141(5):1818-1830.e2.

51. Ma CA, Stinson JR, Zhang Y, et al. Germline hypomorphic CARD11 mutations in severe atopic disease. Nat Genet. 2017;49(8):11921201

52. Ben-Khemis L, Mekki N, Ben-Mustapha I, et al. A founder mutation underlies a severe form of phosphoglutamase 3 (PGM3) deficiency in Tunisian patients. Mol Immunol. 2017;90:57-63.

53. Zhang $Y$, Yu X, Ichikawa $M$, et al Autosomal recessive phosphoglucomutase 3 (PGM3) mutations link glycosylation defects to atopy, immune deficiency, autoimmunity, and neurocognitive impairment. I Allergy Clin Immunol. 2014; 133(5):1400-1409.e5.

54. Sassi A, Lazaroski S, Wu G, et al Hypomorphic homozygous mutations in phosphoglucomutase 3 (PGM3) impair immunity and increase serum IgE levels. J Allergy Clin Immunol. 2014;133(5):14101419.e13.

55. Felgentreff K, Siepe M, Kotthoff S, et al Severe eczema and Hyper-IgE in LoeysDietz-syndrome. Contribution to new findings of immune dysregulation in connective tissue disorders. Clin Immunol. 2014;150 (1):43-50.

56. Lyons JJ, Liu Y, Ma CA, et al. ERBIN deficiency links STAT3 and TGF- pathway defects with atopy in humans. J Exp Med. 2017;214(3):669-680.

57. Candotti F. Clinical Manifestations and Pathophysiological Mechanisms of the Wiskott-Aldrich Syndrome. J Clin Immunol. 2018;38(1):13-27.

58. Somech R, Lev A, Lee YN, et al. Disruption of thrombocyte and T lymphocyte development by a mutation in ARPC1B. J Immunol. 2017;199(12):4036-4045.

59. Kahr WHA, Pluthero FG, Elkadri A, et al. Loss of the Arp2/3 complex component ARPC1B causes platelet abnormalities and predisposes to inflammatory disease. Nat Commun. 2017;8:14816.

60. Kuijpers TW, Tool ATJ, van der Biil I, et al. Combined immunodeficiency with severe inflammation and allergy caused by ARPC1B deficiency. J Allergy Clin Immunol. 2017;140(1):273-277.e10.

61. Barzaghi F, Passerini L, Bacchetta R. Immune dysregulation, polyendocrinopathy, enteropathy, $\mathrm{x}$-linked syndrome: a paradigm of immunodeficiency with autoimmunity. Front Immunol. 2012;3:211. 